AperTO - Archivio Istituzionale Open Access dell'Università di Torino

Immigrants, domestic labor and women's retirement decisions

This is a pre print version of the following article:

Original Citation:

Availability:

This version is available http://hdl.handle.net/2318/1558639

since 2016-03-24T10:47:44Z

Published version:

DOI:10.1016/j.labeco.2015.07.004

Terms of use:

Open Access

Anyone can freely access the full text of works made available as "Open Access". Works made available under a Creative Commons license can be used according to the terms and conditions of said license. Use of all other works requires consent of the right holder (author or publisher) if not exempted from copyright protection by the applicable law. 


\title{
Immigrants, Household Production and Women's Retirement
}

\author{
Giovanni Peri (University of California, Davis) Agnese Romiti (IAB) \\ Mariacristina Rossi (University of Torino)
}

\begin{abstract}
Women contribute disproportionately to household production, especially in Southern European countries. As a consequence of population aging assistance to elderly parents, rather than child care, has become a prevalent activity in home-production services. Immigrant labor has increasingly become a substitute for women labor in those services. Their presence, therefore, may allow women over 55 to work more outside of the house and retire later. We use a unique database of Italian households to identify the effect of local availability of foreign workers on planned retirement age and labor supply of Italian women. We find that an exogenous increase by one point in the immigrant percentage of the local population increased the planned retirement age of women over 45 by two months relative to similar men. For over 55 women with old parents the increase was four months and if they were in low-wealth households the increase was one full year. The same inflow of immigrants also increased the probability that women over 55 work outside the home by nine percentage points, relative to men.
\end{abstract}

Keywords: International migration, retirement, labor supply, home production, elderly care.

JEL codes: J22, J26, F22. 


\section{Introduction}

In this paper we analyze how changes in the local presence of immigrants affected the labor supply and retirement decision of women over 45 in Italy during the period 2000-2008. As argued in several papers (e.g. Burda et al., 2008) most of the house work in Italy (as in several other countries) is performed by women whether they work in the labor market or not. In the recent years immigrants have provided a significant increase in the supply of labor for home-services especially the care of elderly people. The local availability of care at affordable cost may have affected the decision of work and retirement of women, especially if they have older parents. In this study we ask: "do women, 45 and older, in regions with a large supply of immigrant labor, work more and retire later than those in regions with low supply of immigrant labor?" and "Is this effect stronger for women with older parents?".

In the existing literature the analysis of the effects of immigration on female labor supply has focused prevalently on women during child-rearing years and on the availability of immigrants as baby-sitters and nannies (e.g. Barone and Mocetti, 2011; Cortès and Tessada, 2011; Cortès and Pan, 2013; Farrè et al., 2011 ${ }^{1}$ ). However, in countries where the house work is still predominantly done by women, and where fertility rates are low and average age is high (as in Southern European countries during the recent decades) a large share of the household responsibilities of adult women has moved from child-rearing to the care of elderly parents. Moreover in Southern European countries the strong emphasis on family ties makes arrangements such as retirement homes much less preferred than assisted living in one's own homes. As a consequence the increased availability of immigrants in local markets provided an important substitute for women's house work. The affected agegroup is that of women with old parents (hence in their 50's or 60's) rather than younger women. These women may adjust their retirement and labor supply decisions based on the local availability of immigrant labor. This study analyzes the link between local immigration, the presence of elderly parents and the labor supply and retirement decisions of women, 45 years and older, using a unique dataset relative to Italian households.

Italy represents an ideal case to test such hypothesis. First, women participation in the labor market is still low revealing a rather traditional society (female employment/population ratio was $46 \%$ in 2010 , one of the lowest in Europe). Second, Italian women, even when working in the labor market, still perform the lion share of home production services (such as home care, raising children and assisting elderly or disabled family members). A first look at the aggregate statistics provide evidence supporting this imbalance. For instance, the time spent by Italian women, 45 years and older, caring for family members is on average almost twice as much as the time spent by men (13.53 vs. 7 hours per week). These figures are shown in Table 1. The gap does not disappear once we control for the employment status: working women still spend 3 hours more than men in house work

\footnotetext{
${ }^{1}$ Farrè et al. (2011) is the only study looking also at the contribution of immigrants on the labor supply of 25-64 women with elderly relatives.
} 
(9 vs. 6 hours) whereas non-working women spent 7 hours in house work more than non-working men (16 vs. 9 hours). This gap widens further when an older $(80+)$ parent is present in the household: women spend more than 13 hours as opposed to the 6.12 of men (and the gap widens even further for the sample of older women, 55 years and older). Women with older parents spend 17 hours per week caring for family members compared to only 7 hours spent by men. In a cross-country perspective, this evidence is also confirmed by Burda et al. (2008) who look at time-allocation data for European Households.

In Italy strong and persistent familial ties between children and their parents, accompanied by the low mobility of young people, have encouraged families to care for their elderly. Publicly provided residential care covers only $3 \%$ of those aged 65 and over (Presidi residenziali socio-assistenziali e sanitari, 2009, ISTAT). Institutions for the elderly (such as convalescent homes) care for only three out of 1000 people aged 65 and over. They are perceived as being much less desirable than caring for the elderly in their own home. As a consequence, during the last two decades the paid care for the elderly and the disabled (in Italian: "Assistenti e Badanti") has expanded dramatically. This sector has been dominated by foreign workers. Italian citizens, especially those in young cohorts, supply almost no labor to these services.

Our data, a representative survey of Italian households, contain very detailed information on family structure, employment and retirement decisions and planning. This allows us to analyze the impact of immigrant labor on the planned age of retirement of Italian women (and men), accounting for their family characteristics. In particular, we analyze whether the increased presence of immigrant labor in a region, as predicted by the presence of specific national enclaves before 2000, affected the planned retirement age of women over 45 (relative to men) and whether this effect was stronger for those with living elderly parents (relative to women with no living parents). We also analyze whether the immigrant labor has had an impact on the labor supply, particularly on that of women. Hence, this paper contributes to the literature on the impact of immigration and to that on the determinants of the retirement age.

Empirical evidence has reported that the care for parents inevitably affects working and retirement decisions (Bolin et al., 2008; Carmichael and Charles, 1998, 2003; Crespo and Mira, 2010; Kolodinsky and Shirey, 2000; Wolf and Soldo, 1994) and particularly those of women in Italy (Marenzi and Pagani, 2008), given their traditional role as care-givers (Lamura et al., 2008). Our findings indicate that in regions with a large increase in immigration women stay employed longer. In a country as Italy, where a series of reforms has increased the retirement age of individual through increasing mandatory working age, our paper proposes an interesting, if more limited, market-based mechanism to achieve an increase in retirement age: increase the supply of immigrants hence reducing the cost of the care of elderly parents, enabling women in their 50's and 60's to continue to work outside the home.

The main findings of our analysis are as follows. First, an increase in the employment share of immigrant 
workers in a region has a positive effect on the employment probability of women over 45 years of age. Second, it increases significantly their planned retirement age as compared to similar men. Despite finding a positive effect on the probability of working full time for women, we do not find significant effect on hours worked, possibly due to the rigidity of the Italian labor market system, in which changing the length of the working week can be hard for a 50 year old working woman. Third we find that those effects are stronger in households with women over 55 years of age who also have a parent aged 80 years or older. These findings are all consistent with the idea that immigrants are substitutes for women in home-production especially in providing care of their elderly parents.

The rest of the paper is organized as follows. Section 2 provides a review of the relevant literature on the impact of immigration and on the determinants of female work and retirement. Section 3 presents the empirical specification and discusses the identification strategy. Section 4 describes the data used and Section 5 discusses the results obtained. Section 6 considers the differences in the labor and retirement response of women depending on their family type. Finally, the paper is concluded with some remarks by Section 8 .

\section{Basic Facts and Literature Review}

Immigration has been a steadily increasing phenomenon in Italy during the last twenty years. In 1991 immigrants represented only $0.6 \%$ of the total resident Italian population. In 2011 , they reached $8 \%$ of the total population (ISTAT) corresponding to over 4 million individuals. Figure 1 shows the trend in net immigration as share of the population (yearly inflow divided by the resident population) over the period 2000-2010, by macro-area of origin. Eastern Europe, responsible for $92 \%$ of new European immigrants in 2010 was the fastest growing group. Moreover the home-service sector has become increasingly dominated by foreign workers. Considering only workers registered to the Italian National Social Security Institute (INPS), the percentage of immigrants in the household services sector increased from 51\% in 2000 to $80 \%$ in 2008 . Between 2002 and 2010 the employment of foreign house-service workers increased by $78 \%$ vis-a-vis an increase of natives by $26 \%{ }^{2}$

This paper is related to the literature about the impact of immigration on labor market outcomes of natives. Most of the literature has focused on the competition/complementarity effects of immigrants in affecting the labor market for native workers. ${ }^{3}$ A series of papers, recently, investigated the relationship between immigration and native labor supply (Barone and Mocetti, 2011; Cortès and Tessada, 2011; Cortès and Pan, 2013; Farrè et al., 2011). Cortès and Tessada (2011) show that low-skilled immigration, by reducing the cost of household

\footnotetext{
${ }^{2}$ These percentages are likely to under-estimate the actual contribution of immigrants, as their vast majority is not registered with the INPS, since they do not have a regular contract.

${ }^{3}$ See Borjas, 2003; Borjas et al., 2008; Card, 1990, 2001, 2009a,b; D'Amuri et al., 2010; Dustmann et al., 2005; Gavosto et al., 1999; Manacorda et al., 2012; Ottaviano and Peri, 2012; Peri, 2007; Peri and Sparber, 2011; Staffolani and Valentini, 2010; Venturini and Villosio, 2006 among others.
} 
services, increases the labor supply of young educated women, reducing their time spent in caring for their children and increasing their expenditure on housekeeping services. For Italy, Barone and Mocetti (2011) find similar results, showing that female immigrants who specialized in household production increase the labor supply of highly-educated Italian working age women by increasing their working hours. Also Cortès and Pan (2013) find that temporary domestic migrant workers have increased female labor force participation rates for women in Hong Kong and the effect has been particularly large for highly educated women with young children. No previous study, to the best of our knowledge, has looked at the effect of immigration on retirement decision. The closest study to ours is Farrè et al. (2011), who analyze the impact of female immigration to Spain on the labor supply of highly educated native women, with a particular focus on women with family care commitments, such as children or elderly relatives living with them. Among others, one of their findings shows that female immigration rises the probability of working for highly skilled women with elderly relatives. Our paper differs from their in three main aspects. First we focus on the (more appropriate) age range ${ }^{4}$ in order to isolate the potential users of immigrants for elderly care. Second we can identify whether the head of a household or his/her spouse has a living elderly parent. Third we are the first to analyze the impact on planned retirement age.

There is also an abundant literature on the determinants of retirement. Within this body of literature, the paper of Stock and Wise (1990) stands out as the seminal work which explains the choice of retirement according to the Option Value (OV) model. This model considers the different utilities associated with immediate retirement versus the utility associated with postponement. The agent, if rational, would choose the option with the highest corresponding utility, which is the best of the alternatives. Several papers have drawn on the seminal contribution of Stock and Wise (1990) and evaluated, using this model, the effectiveness of some policies and of financial incentives in affecting retirement age. Brugiavini and Peracchi (2004) and Belloni and Alessie (2009, 2013) are such examples. Cross-country evidence is considered in Gruber and Wise (2004), who apply the same template to 12 OECD countries by running a reduced form of the OV model and simulating different policy scenarios, and provide strong support for the significant causal effect of financial incentives on retirement decisions. ${ }^{5}$ The literature on the determinants of retirement age has recognized that the needs of elderly parents may act as a disincentive to continue working. Retiring earlier allows workers with living parents to care for them and to avoid buying long-term care on the formal market which can be very expensive. Some studies have analyzed the effect of affordable care options on the labor market outcomes of households. They use data from the US (Ettner, 1996; Kolodinsky and Shirey, 2000; Wolf and Soldo, 1994), with fewer cases analyzing the UK (Carmichael and Charles, 1998, 2003), a few cross-country studies of European countries (Bolin et al., 2008; Crespo and Mira, 2010) and one study on Italy (Marenzi and Pagani, 2008). All of these studies point

\footnotetext{
${ }^{4}$ The authors consider women of 25-65 years as opposed to our analysis looking at 45-70 years.

${ }^{5}$ Samwick (1998) represents another relevant study which applies this reduced-form version of the OV model for the case of the US.
} 
out the positive relationship between the availability of care for the elderly and labor market supply, at either the intensive or the extensive margin.

\section{Empirical Framework}

\subsection{Basic Specification}

Our empirical strategy is based on a simple specification relating the outcome (or choice) $y_{\text {irt }}$ for individual $i$ in region $r$ at time $t$ to a series of individual controls and to the share of immigrants in the regional labor market $\left(f_{r t}\right)$. Importantly, we also include in the regression the interaction of the immigrant share with gender and with the presence of elderly parents. The basic specification is as follows:

$$
y_{i r t}=\phi_{i}+\phi_{t}+\alpha X_{i r t}+\beta f_{r t}+\gamma_{1} \text { female }_{i} * f_{r t}+\gamma_{2} \text { female }_{i} * \text { old parents }_{i r t} * f_{r t}+\varepsilon_{i r t}
$$

The dependent variable $y_{\text {irt }}$ is, alternatively, the expected retirement age or a dummy for being employed, or for working full time or the number of hours worked, conditional on working. The term $\phi_{i}$ represents a set of individual effects capturing the time invariant individual characteristics (including gender). The term $\phi_{t}$ captures a set of year fixed effects. The vector $X_{i r t}$ includes individual time-varying characteristics such as age, age squared, marital status, partner's employment status, education, ${ }^{6}$ and the logarithm of net wealth. We also include among those controls the indicator "old parents", a dummy capturing the presence of at least a living elderly parent (or parent in law) over the age of 80 and its interaction with the female dummy. We also control for parental economic conditions by using an indicator for having at least one old parent (or parent in law) whose last occupation was as a blue collar or unemployed. In the specification that includes planned retirement age as outcome we also include individual controls based on the determinants of retirement age in an Option Value model. Those are the eligibility for seniority pension (as it changed over time according to requirements based on age and seniority), occupational dummies and a measure of financial incentives given by the predicted option value of retiring. ${ }^{7}$ The variable $f_{r t}$ is the share of foreign-born in the population of region $r$ in year $t$. Finally the term $\varepsilon_{i r t}$ captures all the zero-mean idiosyncratic random shocks to the outcome variable for individual $i$ in period $t$. The focus of the analysis is the estimate of the coefficients $\gamma_{1}$ and $\gamma_{2}$. The first coefficient identifies whether a change in the share of immigrants in the region produces a differential effect in the outcome of men and women. If $\beta$ captures the average effect of immigration on male individuals, channeled through labor market and general equilibrium effects, $\gamma_{1}$ identifies the additional effect of immigrants on women labor supply or retirement decision. Even more importantly $\gamma_{2}$ identifies the additional effect of immigrants on

\footnotetext{
${ }^{6}$ We consider three dummies corresponding to compulsory education, high school, and higher education, with the excluded category representing no education.

${ }^{7}$ For the computation of the predicted measure of the OV see the Appendix.
} 
women labor supply (or retirement decisions) when they have an elderly parent. If immigrants have an effect in substituting for house services then their impact in encouraging participation to the labor market, should be stronger for women (positive value of $\gamma_{1}$ ), and particularly for those women with living elderly parents (positive value of $\gamma_{2}$ ). In the empirical analysis we break down the sample according to different age brackets in order to isolate the different role of family care commitments and also to isolate the sample where the expectations about retirement are likely to be affected by current conditions. For the retirement estimation we concentrate on two age brackets: 45-70, and 55-70. We use the same two age brackets for the analysis on the intensive margin of labor supply (weekly working hours and full time indicator), whereas we include the additional sample of 60-70 years old for the analysis on the extensive margin (working or not). The other dependent variables contain too many missing values in the sample 60 years and older to be usable.

\subsection{Identification and IV strategy}

Our data set includes individual observations spanning the period 2000-2008 every other year. We exploit the longitudinal dimensions of the data and we estimate equation (1) using a fixed effects estimator to control for unobserved individual characteristics. This approach can still produce inconsistent estimates of the causal impact of immigration on women employment and retirement decisions if omitted variables at the regional level affect both changes in immigration and changes in the incentives to retire and to work. The inclusion of fixed effects, the presence of the controls and, most importantly, the focus only on the differential effect between men and women will absorb a large number of unobserved factors that affect individual labor market outcomes and may be correlated with immigration at the regional level. Only economic factors that affect differentially men and women, and specifically women with older parents, and are correlated with local immigration would generate an omitted variable bias in the OLS estimates. Nevertheless, in order to reduce even further the presence of these unobservable factors, we use, as preferred model, an instrumental variable estimator. The most insidious omitted variables would be region-level demand shocks that attract immigrants and affect the retirement and labor supply decisions of native women relative to native men. Positive demand shocks to sectors mainly hiring women may constitute such factors. In that case the FE estimate would be biased upwards. In the empirical analysis we also show that our results are robust to potential confounding gender-specific labor demand factors by controlling for men and women unemployment rates (at the regional level). In addition, our measure of the immigration share of the population may be affected by measurement errors, as it only accounts for legal resident immigrants and is based on a sample rather than on the total population. ${ }^{8}$ This type of measurement error introduces a downward bias in the FE coefficient. In one of the robustness checks we try to address this issue by quantifying the impact of the unaccounted illegal immigrants on our findings by using the information

\footnotetext{
${ }^{8}$ According to estimates based on ISMU (Iniziative e Studi sulla Multietnicità) data and provided by Blangiardo and Cesareo (2009) in year 2000, undocumented represented $10 \%$ of resident immigrants.
} 
taken from the 2002 Amnesty.

The IV strategy that we adopt is broadly used in the literature on immigration. Our estimates exploit the variation in the immigrant share of the population over time within regions: we have 20 regions in total and a time span of 8 years distributed in 5 waves (2000-2008), due to the structure of the Survey which is run every two years. Table 2 shows the variation in the immigrant share of the population in each region at the beginning and at the end of the considered period. One can see that there is a significant variation across regions in the increase in the immigrant share. In particular we use as instrument the supply-push component of immigration, following Card (2001). The rationale behind the instrument rests on the use of the regional pattern of settlement of immigrants from a given source country in the past as an exogenous determinant of the subsequent local country-specific flow of immigrants. The total country-specific flow of immigrants to the host country between 2000 and 2008 is distributed according to the regional shares as of 1991. Hence the demand shocks, that may affect immigration over the considered period, do not contribute to the correlation between the instrument and the dependent variable.

Specifically the instrument for the immigrant share in region $r$ at time $t$, that we will call "imputed immigrant share" and denote as $\widehat{f}_{r t}$, is computed according to the following formula:

$$
\widehat{f}_{r t}=\frac{\Sigma_{c}\left(\frac{I m_{c r t_{0}}}{I m_{c t_{0}}}\right) I m_{c t}}{\operatorname{Pop}_{r t_{1}}}
$$

In the formula (2) the term $\frac{I m_{c r t}}{I m_{c t_{0}}}$ represents immigrants born in country $c$ residing in region $r$ at time $t_{0}$ relative to all immigrants from country $c$ residing in Italy in year $t_{0}$. The year chosen to determine the initial regional distribution of immigrants across regions is $t_{0}=1991$ and we rely on Census data for that year. ${ }^{9} \operatorname{Im}_{c t}$ is the stock of immigrants from country $c$ present in Italy as of year $t$, and $P o p_{r t_{1}}$ is the total resident population in region $r$ computed in 2000, the first wave of our analysis. Both of those values are taken from population registry data.

As we use the variation of this index over time to identify the impact of immigration the validity of this strategy relies upon two main requirements: first, the distribution of immigrants across regions, by nationality, as of 1991 should be uncorrelated to local demand shifter in the period 2000-2008, especially those affecting relative changes in employment of women that are not observable. Second, the distributions of immigrants across regions in 1991 must be correlated to regional flows in the 2000-2008, because of network effects. This ideas is strongly supported by the broad empirical evidence on the tendency of newly-arrived immigrants to cluster in areas which are highly populated by immigrants from the same country following pre-established networks (Aslund (2005) and Damm (2009) provide two examples for Sweden, Cutler et al. (2008) for the US). Table

\footnotetext{
${ }^{9}$ In the Data section we describe in greater detail both the data used for the implementation of the instrument and the sample of selected immigrants.
} 
3 shows the predictive power of the instrument using the aggregate region-time regression of the dependent variable on the imputed share defined in (2). In the first specification we do not include any other control, in specification (2) we include region and year effects, relying therefore on the within region change over time; in specification (3) we add controls for the average regional level of the variables included in the individual specification. Finally in specification (4) we control for the regional female and male unemployment rate. The coefficient estimates show that the instrument is a strong predictor of the share of immigrants, implying that the historical (1991) distribution of immigrants by nationality is a good predictor of their later inflow.

In the individual regressions (1) that we estimate beginning in section 5 we include not only immigrants as share of the population, but also the interaction of this variable with female and old-parent dummies. In the estimation we consider also these interactions as potentially endogenous and we instrument them with the imputed share (2) interacted with those same dummies. We end up with four endogenous variables and four instruments and the joint F-statistic of the instruments is somewhat weak. Hence we also perform a reduced form regression, in which we enter directly the IV and the IV interacted with "female" and "old parents" as explanatory variables. All Tables of results reported below, show the predictive power of the instrument, by reporting the first stage joint F-statistics of the instruments and, for the main results, we also report the estimates of the reduced-form regressions, where we include the imputed immigration rate and its interaction directly in the regression.

\section{Data: Description and Summary Statistics}

Our empirical analysis relies on three different sources of data. The Survey on Household Income and Wealth (SHIW for brevity) provides all the individual variables; the administrative registry includes data on the total resident and immigrant population and the 1991 Census data has the information needed to compute the regional distribution of immigrants as of 1991 used to construct the instrument as described in (2).

The SHIW survey, which has been run since 1965 by the Bank of Italy on a large and representative random sample of the Italian population is the main source of data. The latest available wave is for year $2010 .^{10}$ Until 1987, the sample was only cross-sectional, whereas since 1989, the survey has introduced a sub-sample of panel households. Every two years, the survey gathers information on about 8,000 households corresponding to about 24,000 individuals and provides data about the income, wealth, work-related and sociodemographic characteristics of family members. Since 1993, a special section has been devoted to collecting information about the family background of the head of the household and his/her spouse. Detailed information is provided about non coresident living parents, their age, their highest attained educational level and their occupation at

\footnotetext{
${ }^{10}$ Despite being available we cannot use the last year 2010 because the information of the parental living status - crucial for our analysis - is not available.
} 
the time when they were the same age as the respondent.

When analyzing retirement decisions as dependent variable, we use the information provided by the survey on the planned retirement age. Individuals are asked the following question: "At what age do you expect to retire?" The information on the planned retirement age has been available since the year 1989 for all waves. The survey also elicits information about the expected replacement rate at the time of retirement by asking the following question: "Think about when you will retire, and consider your public pension only (that is, exclude private pensions, if you have them). At the time of retirement, what fraction of your labor income will your public pension be?" This question is only available for the following years: 1989, 1991 and all years between 2000 and 2008. The current replacement rate and the replacement rate at time of planned retirement allow us to calculate the option value of delaying retirement, ${ }^{11}$ which we use as an explanatory variable in regression (1). The planned retirement age turns out to be a good proxy for the actual retirement age; the correlation coefficient between the two variables is equal to 0.727 , the average value of their difference is 0.615 , whereas the median value of the difference is equal to 0 . In addition to the planned retirement age we also consider different measures of labor supply. Accordingly we consider three different variables: a binary indicator for working or not, the logarithm of hours worked per week, and a binary indicator for working full-time versus working part-time.

The second source of data, represented by the residential registry data, includes information on the resident native and immigrant population at the regional level, by country of origin. This source of data serves two purposes in our empirical analysis: first we use it to compute the immigration share by region, the explanatory variable of interest. ${ }^{12}$ Second, we use the total number of resident immigrants by year and country of origin to compute the term $I m_{c t}$ used to construct the instrument.

As we do not have information about the skill level of the immigrants, in order to focus on immigration that mainly brings low-skilled workers in Italy, we limit our measures to immigrants who were born outside Western Europe and North America. This choice is supported by the evidence about the distribution of education by country of origin provided by the EULFS (European Labor Force Survey). By using this data relative to years 2005-2008 ${ }^{13}$ we see that in Italy immigrants from EU15 and from North America are the most educated. 35\% of EU15 immigrants and 57\% of North America immigrants have high (tertiary) education relative to only $14 \%$ of Italians. For the construction of the instrument, we disaggregate the immigrant population according to groups of countries of origin. Similarity in cultures and traditions drives the tendency to locate in the same areas (Aslund, 2005; Cutler et al., 2008; Damm, 2009). We categorize immigrants into the following five macroregions: Asia; Africa; Latin America; Eastern Europe (non-EU) and others. The 1991 Census of population is

\footnotetext{
${ }^{11}$ For the details of its computation see the Appendix.

${ }^{12}$ This number may underestimate the total presence of immigrants as it is not compulsory to be registered for immigrants. It has been estimated that Registry data account for about $88 \%$ of immigrants regularly present in Italy (ISTAT) and the correlation with total number across regions is very high.

${ }^{13}$ Before 2005 the classification of country of origin only distinguishes between EU-15 and non EU-15 countries.
} 
the third source of data that we use to compute the historical regional distribution of immigrants as of 1991 and to implement our instrument. Table 2 reports the immigrant population share by region and over time; the table reveals that there is substantial variation of the immigrant share of the population both by region and time, and there are no outliers potentially affecting the estimates.

Given the broad empirical evidence that immigrants represent the largest share of workers employed in the long-term care sector ( $80 \%$ in 2008; INPS) and that $31 \%$ of immigrant workers are employed in low-skilled occupations (LFS, 2008), a large inflow of immigrants, as measured by an increase in the immigrant share of the population, could have a substantial impact on the local labor supply for the household services sector. At the same time immigration can affect labor supply decisions of family through its effect on local wages (Gavosto et al., 1999; Romiti, 2011; Staffolani and Valentini, 2010). It is very likely however, that the labor market channel affects the labor supply of all workers, while the first channel affects mainly women, who are the main providers of household services, and in particular women with elderly parents. By including in (1) the interaction of the dummy female and of the presence of elderly parents with the share of immigrants we aim to isolate such an effect.

The sample used in the analysis includes native heads of household and their spouses 45 to 70 years old. For the regressions explaining retirement age we include all employed workers. To estimate the effects on the labor supply we also include unemployed, stay-at-home individuals and retired individuals. This implies that the sample on which we estimate labor supply decision is larger than the one used to estimate expected retirement age. The "planned retirement" sample consists of a panel of 7,876 observations and 1,561 individuals, 40 percent of whom are women (Table 4 reports the summary statistics for the variables included in the analysis). ${ }^{14}$ The average planned retirement age is 61 , and immigrants represent $4 \%$ of the regional population. Only 4 percent of the sample is eligible for a seniority pension. This percentage rises to 14 percent when we restrict the analysis to workers 55 years and older. 56 percent of the sample is employed in white collar types of jobs (including teachers, office workers, and junior managers), whereas 5 percent of them work as managers, university Professors, or in other similarly high skilled jobs. The share of persons with tertiary education (13.8\%) is in line with the average value for the Italian population 14.4\% (2008, EUROSTAT). Almost 40 percent of individuals have at least one old living (non coresident) parent or parent in law. ${ }^{15}$ Table 5 shows the evolution of the planned retirement age for men and women over the years. In the Table we distinguish individuals with and without elderly parents. Focusing on the age group over 55, we see that women have increased their planned retirement age by a year or more between 2000 and 2008, while men have experienced no change. Moreover, the increase in retirement age

\footnotetext{
${ }^{14}$ All descriptive statistics are weighted by using the survey sampling weights.

${ }^{15}$ The presence of co-resident parents or parents in law can be identified for the head of household, only in 2008 we have this information for both partners. However only 1 percent of the 2008 sample live with an old parent.
} 
was larger for women with elderly parents (1.4 year) than for those without (0.9). These two facts are consistent with the ideas that the significant growth of immigrants as home-service workers might have helped women, especially those with older parents, to delay their retirement.

Turning to the labor supply sample Table 6 shows the summary statistics; relative to the "planned retirement" sample this one also includes non-employed and retired persons. This sample corresponds to 2,526 individuals and 15,763 observations. About $45 \%$ of the individuals are women and their mean age is 56 (older than the previous sample as some retirees are included). The other difference, relative to the "planned retirement" sample, is a lower share of highly educated individuals (10\% versus $13.8 \%) .54$ percent of the sample is employed, and among the employed, the average working hours are 37.213 per week. The very high percent of full-time contracts reflects the rigidity of the Italian labor market that hardly allows part-time work. In this sample $35 \%$ of individual has at least one old living parent or parent-in law.

Finally Table 7 shows the evolution over the time of the different margins of labor supply: probability of working, average hours worked per week and probability of working full time. Considering the older group, 55 and above, we notice that the share of working people increased over time for both gender. Among individuals with old parents, however, the increase is substantially more pronounced for women $(+0.22)$ than for men $(+0.10)$. Average working hours per week were essentially constant for men, whereas they increase for women, in particular if older and with older parents. The evidence on the probability of full time employment confirms the rigidity of the Italian labor market since the share of part time workers is extremely low. Almost all men work full time, whereas the share of women working full time grows only for those with elderly parents. Overall, the trends in planned retirement age and in labor supply shows significant increase in labor participation and delayed retirement, especially for women with elderly parents over the 2000-2008 period.

\section{Results: Basic Specifications}

Table 8 shows the estimates of the relevant coefficients in the basic specification (1) when the dependent variable is planned retirement age. The first four columns report the estimates obtained using OLS and including individual fixed effects and controls, while columns (5) to (8) show the 2SLS estimates of the same specifications using the "imputed" immigrant share as instrument. We report results for different samples (45 and older, 55 and older) to see whether the effects is stronger on older women. We show a specification including only the differential effect of immigration on women outcomes (even columns), as well as a specification including the differential effect for women and the additional interaction between women and old-parents dummy. Our preferred one is specification (8) that uses 2SLS estimation, and includes older individual (55 and older), closer to retirement whose current circumstances are more likely to affect decisions on retirement age. The coefficients in the first row show the basic effect for men. Those in the second row show the differential effect of the share of 
immigrants on women's planned retirement age. Those in the third row show whether the presence of old parents affected the impact of immigrants on the men's retirement decisions. Those in the fourth row show the additional effect of immigrants on planned retirement age of women with living old parents (80 years and older). Each regression also includes individual fixed effects, the dummy "Old parents", and its interaction with the female dummy, an indicator for living parents being old and low income, the predicted Option Value of retirement for the person, the logarithm of net wealth of the family, a dummy for eligibility in seniority pension, a dummy for having an employed partner, dummies for educational attainment, occupational dummies, a dummy for marital status, age, age squared and year dummies. Since we are interested in the differential effect of immigrants on women's retirement, we mainly concentrate on the coefficients $\gamma_{1}$ and $\gamma_{2}$ from equation (1) reported in the second and in the fourth row of Table 8 . As the main explanatory variable, the share of immigrants in the region, only varies by region and year we cluster the standard errors by region to correct for the potential correlation between errors across individuals within a region.

Focusing on the 2SLS results of Table 8 we see that the immigration share of the population in the region increases significantly planned retirement age, for women relative to men. Women over 55 in a region where immigration grew by one percent of the population increased their planned retirement age by one third of one year, vis-a-vis similar men. For women over 45 the relative increase was a sixth of one year. The share of immigrants in the region, on the other hand, had a negative effect on men's retirement age (the main effect), implying that possibly the labor market competition or complementarity effects of immigrants pushed native males to reduce their planned retirement age. When considering the specification that includes the additional regressors indicating the presence of old parents and their interactions with gender and immigrant share we find that the positive impact of immigration on females' planned retirement age remains unchanged for women over 45. However, considering the older age bracket ( 55 and older) in the last column of Table 8 we see that most of the positive effect on women retirements comes through the effect on women with older parents. Since the burden of care for older parents may emerge more clearly later in life and individuals make more precise plans for retirement when approaching retirement age, focusing on older respondents may increase the precision of the estimates. For the older sample, not only the immigrant share of the population has a larger impact on women's planned retirement age in the basic specification, but that effect is mainly due to women with older parents. These are interesting and new results. Immigration may allow women to delay retirement, especially when those women have to care for an older parent. Men's decisions overall are less affected by the regional immigration share (and if anything the main effect is negative). These results seem consistent with the idea that immigrants, especially less educated, are good substitute to the services otherwise provided by women in the household. Their presence reduces the incentives for women to retire early. The OLS specifications provide similar results with lower coefficients suggesting that omitted regional variables (such as working opportunities 
for young people, or past growth of the economy) may actually affect the retirement age of women and the inflow of immigrants in opposite directions. Correcting that bias results in higher estimated effects. The lower part of Table 8 shows the results from the reduced form regressions in which we have included the instrument and its interactions directly in the regression, and otherwise we use the same specifications as the 2SLS regressions. As the F-statistics of joint significance of the instrument are not too strong, it is reassuring to see that the reduced form regression produces very similar coefficients and similar significance level, as the 2SLS regressions. For the group of people 55 and older the largest and most significant effects of immigration on planned retirement age is the one for women with living older parents (fourth row of last column).

Turning to the effect of immigration on the labor supply of men and women, Table 9 shows the estimates of specification (1) when the dependent variable is a dummy equal to one if the individual is working and to 0 if he/she is not. As for Table 8 we show the estimates using OLS (first four columns), 2SLS method (columns five to eight), and the reduced form regression coefficients (below the 2SLS). In this case we use different age samples, including an older one, 60 and above, and the one 55 and older that produced the clearest results in Table 8. Focusing on the 2SLS and on the reduced form estimates, two results emerge very clearly. First, immigration while having a negative effect on the labor supply decision of native males, possibly due to labor market competition, has a significantly positive differential effect on the labor supply of women. Combining the two we obtain larger probability of working for women over 55 in regions with higher share of immigrants. This differential positive effect on women increases in strength as we consider the groups of older women (age 60). ${ }^{16}$ The increase in immigrant labor availability allows women, especially those in older age brackets, to work more outside the house.

Second, while it is clear from the main interaction (Old parents)x(Female) that the presence of older parents reduces the probability of women working, relative to men, it is also clear that the increase in immigrant labor (triple interaction) has a positive effect on the labor supply of women with older parents. The effect of an increase of immigrants by one percent of the region population increases the probability of working for women with old parents, by almost $10 \%$ whereas men in the same family would decrease their probability of working by $5 \%$. This is the effect considering the sample of 60 and older. The differential effect of immigration on men and women of an increase of immigrants by 1 percent of the region population, despite significant, is smaller for 55 years and older, whereas the differential effect for women and men with old parents is also positive but not significant. Hence, also on the working-non working decision, and especially for older individuals, the inflow of immigrants seems to have a differential effect, with a stronger positive employment effect for women. The main results of Table 9 are reassuringly similar in the OLS and the 2SLS regressions, and are further confirmed by

\footnotetext{
${ }^{16}$ Only for the specification working/not working we can consider the additional sample of very old respondents aged 60 or over, whereas for the other specifications we end up with having too few observations.
} 
the reduced form regression.

We then move to analyze the effects of immigrants on the other margins of labor supply. The upper part of Table 10 shows the estimated coefficients, when the dependent variable is the average hours worked per week. The different columns show the OLS and 2SLS estimates, for the 45 and older or 55 and older samples including or not the double and triple interactions. The lower part of the Table shows the same specifications when the dependent variable is a dummy for working full time. In these regressions we do not find any significant effect of the immigrant share of the population on hours worked and on their gender differential. The presence of old parents in the family does not contribute either to the effect of immigrants on women's hours supply. We find, however, some evidence of an effect of immigration on the probability that women with older parents switch from part time to full time employment. All specifications (OLS and 2SLS) show a positive effect of immigration on the probability that women with older parents switch to full time (triple interaction). The effect is significant in three out of four specifications although relatively small in size. The very small variation of hours worked by older workers in Italy and of the probability of part-time, due to relatively rigid contractual agreements in the Italian labor market, may explain the lack or the small magnitude of the response of these variables capturing the intensive variation of labor supply.

In order to have an idea of the magnitudes of the estimated effects, we summarized them in Table 14 which is reported in section 6 . In that Table we summarize the effects of a 1 point increase in immigration as percentage of population on women outcomes relative to men's and on the additional effect on outcomes for women with old parents. The Table shows, essentially, the coefficients $\gamma_{1}$ and $\gamma_{2}$ from equation (1) multiplied by a change in the immigrant share of 0.01 . We use the 2SLS estimates for these calculations and we include only effects based on estimates whose significance level is larger then $5 \%$. The top row of Table 14 shows the magnitudes calculated for the whole sample (based on estimates of Tables 8 to 10). The remaining rows report the magnitude of the effects for differentiated groups, based on the analysis that we present in the next section. One point increase in regional immigrants as percentage of the population increases planned retirement age for women by 2.2 months relative to men in the same conditions. In the same regions the retirement date of women is delayed by 4.2 months - compared to that men - for older women with old parents. The overall increase in planned retirement age for women older than 45 is about 4 months in response to the observed increase in immigration (4.7pp) between 2000 and 2008. This explains about $18 \%$ of the 1.7 year increase in planned retirement age observed for women during that period. As for the other outcomes, in response to an increase in immigration of a percentage point of population, the probability of working for women 45 years and older increases by 4 percentage points relative to men. It increases by 9 percentage points for women 55 and older relative to the men in the same age group. Immigration rises the probability of working for the group of women 60 and older by 16 percentage points compared to men, and an additional 9 percentage points for women with older parents. The absolute 
effect on women 45 years and older is less than 1 percentage point, and it increases to 2 and 5 percentage points for older women, whereas the oldest group with old parents increased employment probability by 9 percentage points in absolute terms, due to immigration. In order to understand the relevance of these numbers, we need to compare them to the descriptive evidence, which reports that the labor supply for women 45 years and older increases by 20 percentage points (by 22pp for women older than 55), and by 21 percentage points (and 22pp for 55 and older) for women with old parents. Therefore, using these estimated coefficients, the 4.7 points rise of immigrants as percentage of population occurred over the period 2000-2008 has been responsible for an increase of 3 percentage points in the labor supply of women 45 and older equivalent to 16 percent of the observed $20 \mathrm{pp}$ increase), and for 9 percentage points in the labor supply of women 55 and older (equivalent to 39 percent of the observed 23pp increase).

\section{Heterogeneous effects by household characteristics}

The effect of immigrants on the retirement age and labor supply of individuals may be different depending on their characteristics. The potential wage that they can earn if they work, relative to the cost of hiring an immigrant as house worker, will affect the sensitivity of their labor supply and retirement decisions to the availability of home care. Hence individuals with different skills (earning potential) and wealth (ability to pay) can be affected differentially by the local availability of immigrant labor. We explore the heterogeneity of the impact of immigration by separating individuals with different levels of initial education and wealth. We begin by replicating the previous empirical analysis separately for high and low educated individuals and then separately for individuals with high and low wealth. Table 11 shows the estimates by education group for planned age of retirement (Top panel) and for probability of working (Bottom panel) as dependent variables. Beginning with the breakdown by education groups, we define as highly educated those with at least a high school diploma. We use this definition, as opposed to the more standard one based on tertiary education, because in Italy only about 10 to $13 \%$ of the individuals in the considered age range had a college education. In our sample more than $40 \%$ of the individuals had a high school diploma. Considering planned age of retirement as outcome, it is evident that the main results are driven, mainly, by the response of less educated women. Highly educated women, aged 45 and above, increase their planned retirement age in response to immigration but to a lower extent than the less educated ones. When considering the older group (55 years and above) the difference is even stronger: no significant effect of increased immigration is identified on retirement decision of more educated women, while less educated women increase significantly their planned retirement age and the effect is even stronger for less educated women with an older parent. These results are mirrored by the results on the probability of working (bottom panel); a positive and significant impact of immigration is found only for women and it turns out that both high and low educated women increase their probability of working, even if 
this impact is substantially higher and more significant for less educated ones (in particular for the sample 55 years and older). As for the other two dimensions of the labor supply (weekly working hours and full time/part time, not reported in the Table), the positive effect found for women 45 and older on the probability to switch to full time position is driven by low educated women with old parents. Similarly low educated old women with old parents also respond to immigration by increasing significantly their working time per week, while highly educated ones do not. ${ }^{17}$

We then split the sample according to the wealth of the household. Each respondent's household is classified as "below median wealth" if his/her household net asset worth lies below the median value of the distribution, it is classified as "above median wealth" if his/her household wealth is above the median. Table 12 shows the estimates for each sub-group. We see that for retirement decisions (Top panel) the impact of immigrants is entirely driven by women in household with below-median wealth. In particular, the older sample with old parents shows a very large and significant effect of the triple interaction, denoting that women in low-wealth families with elderly parents are the group most affected by immigrants in their retirement decisions. Very interesting, and also reasonable, is that the simple presence of older parents has a strong and negative effect on the planned retirement age of women, only in "low wealth" households. The scenario is less clear-cut when we consider the effect of immigration on women's labor supply. Both poor and rich women respond to increased immigration by increasing their labor supply. However the effect is stronger for women with old parents who are in low wealth households.

In order to translate the coefficients of Tables 11 and 12 into effects of an increase in immigrant share by 0.01 , the lower part of Table 14 shows the effect of immigration on women's planned retirement age and labor supply, separately by education and wealth. Relative to men in similar conditions low educated women delay their planned retirement age by almost 3 months as a results of a 1 point rise in the regional migrants as percentage of the population. This effect, however is only significant at the $10 \%$ level and not reported in Table 14 . The delay, however, increases to 8 months for older women ( 55 and above) with no elderly relatives, and to 7 months for older low educated women with old parents. As for the highly educated the gain corresponds to almost 2 months and it is only limited to the younger group. Similarly, women in low wealth households, increase retirement age by 4 months ( 8 months if older) in comparison to similar men in response to a one percentage point increase in the immigrant percentage of population. To the contrary the increase in planned retirement for low-wealth women with old parents is more than 1 year relative to similar men. As for the probability of working we find very close results between low educated and low-wealth women. They increase their probability of working by 5 percentage points in response to one extra point in the immigration share, relative to similar men. If old parents are alive, low-wealth or less educated women increase their probability of working by 6

\footnotetext{
${ }^{17}$ The results relevant to working hours and full time are not reported in the paper but are available upon request.
} 
additional percentage points. At the same time high-wealth women seem to benefit more than high educated ones from immigration in comparison to men since they increase their labor supply between 3 percentage points (if younger) and 11 percentage points (if older).

These results taken together suggest that women with lower income and wealth are those mostly affected by the availability of inexpensive household-care possibilities brought by immigrants. While wealthier families may respond less to the cost of care in their retirement decisions, poorer ones and especially women who provide the house care services, are sensitive to such price. More immigration makes care affordable and available encouraging women of less wealthy families to continue working. Affordable home care may entice poorer women to work, while richer ones can afford care and work in the labor market even when it is more expensive.

\section{Robustness Checks}

Omitted local factors, potentially biasing our estimates are specific local labor market conditions. If the demand for women workers is correlated with immigration this can cause a bias. We already control for time invariant factors, affecting men and women differently, through our FE strategy. However there might still be some unaccounted time-variant factors, which could affect our estimation. The first series of robustness check addresses this issue. A second issue, related to measurement errors of immigrant labor, is linked to the fact that we use an imperfect measure of the presence of immigrants in the country. We are not considering illegal immigrants nor unregistered legal ones. It has been estimated that Registry data represent $88 \%$ of the total stock of immigrants regularly present (ISTAT, 2005). Undocumented immigrants, however, are completely unaccounted in our measure. Therefore we perform a correction for this potential mismeasurement by exploiting data from the 2002 Amnesty that pushed several undocumented immigrants to reveal themselves.

To control for gender-specific local labor market conditions we include two variables. First the presence of a daughter between 18 and 35 years old in the household. This may signal weak labor market conditions for women, or also an attitude of the family favoring stay at home women. In either case this can be correlated with the local labor conditions for immigrants and hence their inflow. Additionally we account for local demand conditions by including both the female and male regional unemployment rate (Table 13, various columns). By comparing the results with and without the additional controls we can see that the main finding for retirement (Top panel, Table 13) and probability of working (Bottom panel, Table 13) are robust to the inclusion of these controls. The second robustness check introduces a correction to account for undocumented immigrants using the information provided by the Amnesty of 2002. ${ }^{18}$ As of January 2004, 647,000 immigrants were regularized

\footnotetext{
${ }^{18}$ The law regulating the Amnesty was enacted in October 2002; the law introduced a period for the request of a permit up to November 2003. For this reason we compare the stock of regularized immigrants with resident ones as of 1 January 2004.
} 
by receiving a residence permit (ISTAT, 2005) thanks to the 2002 Amnesty. We thus exploit these information in order to estimate the approximate share of irregular immigrants by region which we use to correct the stock of immigrants that we are using to calculate shares in our empirical analysis. The factor is computed as follows: we first take the stock of residence permits released by regions and we divide this measure of regional irregulars by the stock of resident immigrants ${ }^{19}$ using the Registry data - our measure of immigration. This calculation provides us with a measure of the irregular immigrants relative to the stock of regular ones by region. This measure has a mean value of $31 \%$. We thus correct our regional stock of resident immigrants using this share. The corrected measure of immigration rate has a mean value of $5 \%$ and it is 1 percentage point higher than our original measure. In Table 13 (columns 4 and 8) we compare the results from the original measure of immigration with the ones obtained from the correction. ${ }^{20}$ The main results are confirmed in terms of significance and sign. The only difference is that the coefficients become somewhat lower in magnitude after the correction is applied. As the variation across regions is increased when including the undocumented, the lower coefficients produce essentially the same effect of a change in the explanatory variable by one standard deviation. The fact that the estimates are robust to controlling for undocumented is in line with what has been found by Bianchi et al. (2012), which looks at the impact of immigration on crime in Italy. The authors consider the residence permits as main measure of immigration and they correct the latter exploiting data from different Amnesties. While their method is more sophisticated than ours as they use data from several amnesties, they confirm that there is an extremely high correlation in immigrant shares across regions and over time, when including or when not including undocumented immigrants.

\section{Conclusion}

Italy, among OECD countries, showed some demographic and immigration tendencies during the last decade that are typical of most rich countries. First, the ratio of its old to young population has increased rapidly. Similarly, life expectancy and the associated need for assistance of older people has grown. The retirement and labor supply decisions of their daughters, who have contributed to provide care, have been affected by this. Women, and particularly those with older parents and in poor households, were the group most likely affected by the increasing burden of long-term care. In the same years immigration from non-EU countries has grown. The presence of immigrant labor and its specialization in home-care has been a potentially important substitute for women's work at home. Families could hire affordable and available care-takers among immigrants and hence the women's option to continue participating to employment was increased.

\footnotetext{
${ }^{19}$ Since the resident permits do not count children under age 18 , we try to replicate the analysis excluding minors from the resident immigrant population, and the reported results remain robust.

${ }^{20}$ Only the results for the full specification (equation 1) on retirement and working/not working outcomes are reported, however the results for the other two outcomes are consistent with the ones shown.
} 
Our results show that the inflow of immigrants in the local labor market caused women to delay their retirement and to increase their labor supply, relative to men. In addition, among women the most affected groups are those with older parents, low education and low wealth. Since in a traditional context such as Italy the women are those mainly responsible for the household production, our results can be explained considering immigrants as substitutes for women, especially as care takers of the elderly. Allowing a larger inflow of immigrants in these jobs may help women work longer, and would help especially those with low wealth and hence in larger need of the labor income from working outside of the house. 


\section{References}

Aslund, O. (2005). Now and forever? Initial and subsequent location choices of immigrants. Regional Science and Urban Economics, 35(2):141-165.

Barone, G. and Mocetti, S. (2011). With a little help from abroad: The effect of low-skilled immigration on the female labour supply. Labour Economics, 18(5):664-675.

Belloni, M. and Alessie, R. (2009). The importance of financial incentives on retirement choices: New evidence for Italy. Labour Economics, 16(5):578-588.

Belloni, M. and Alessie, R. (2013). Retirement choices in Italy: What an option value model tells us. Oxford Bulletin of Economics and Statistics, 75(4):499-527.

Bianchi, M., Buonanno, P., and Pinotti, P. (2012). Do immigrants cause crime? Journal of the European Economic Association, 10(6):1318-1347.

Blangiardo, G. and Cesareo, V. (2009). Indici di integrazione. Un'indagine emnpirica sulla realta' migratoria italiana. Franco Angeli Editore.

Bolin, K., Lindgren, B., and Lundborg, P. (2008). Your next of kin or your own career?: Caring and working among the 50+ of Europe. Journal of Health Economics, 27(3):718-738.

Borella, M. and Moscarola, F. C. (2010). Microsimulation of pension reforms: behavioural versus nonbehavioural approach. Journal of Pension Economics and Finance, 9(04):583-607.

Borjas, G. J. (2003). The labor demand curve is downward sloping: Reexamining the impact of immigration on the labor market. The Quarterly Journal of Economics, 118(4):1335-1374.

Borjas, G. J., Grogger, J., and Hanson, G. H. (2008). Imperfect substitution between immigrants and natives: A reappraisal. Working Paper 13887, National Bureau of Economic Research.

Brugiavini, A. and Peracchi, F. (2004). Micro-modeling of retirement behavior in Italy. In Social Security Programs and Retirement around the World: Micro-Estimation, NBER Chapters. National Bureau of Economic Research, Inc.

Burda, M., Hamermesh, D., and Weil, P. (2008). The distribution of total work in the EU and in US. In Working Hours and Job Sharing in the EU and USA: Are Europeans Lazy? Or Americans Crazy?, Boeri, T., Burda, M. and, Kramarz F. Oxford University Press.

Card, D. (1990). The impact of the mariel boatlift on the Miami labor market. Industrial and Labor Relations Review, 43(2):245-257. 
Card, D. (2001). Immigrant inflows, native outflows, and the local labor market impacts of higher immigration. Journal of Labor Economics, 19(1):22-64.

Card, D. (2009a). How Immigration Affects U.S. Cities, pages 158 - 200. Princeton University press.

Card, D. (2009b). Immigration and inequality. American Economic Review, 99(2):1-21.

Carmichael, F. and Charles, S. (1998). The labour market costs of community care. Journal of Health Economics, 17(6):747 - 765 .

Carmichael, F. and Charles, S. (2003). The opportunity costs of informal care: does gender matter? Journal of Health Economics, 22(5):781-803.

Chan, S. and Stevens, A. H. (2004). Do changes in pension incentives affect retirement? a longitudinal study of subjective retirement expectations. Journal of Public Economics, 88(7-8):1307-1333.

Cortès, P. and Pan, J. (2013). Outsourcing household production: Foreign domestic workers and native labor supply in Hong Kong. Journal of Labor Economics, 31(2):pp. 327-371.

Cortès, P. and Tessada, J. (2011). Low-skilled immigration and the labor supply of highly skilled women. American Economic Journal: Applied Economics, 3(3):88 - 123.

Crespo, L. and Mira, P. (2010). Caring for parents and employment of European mature women. Working Papers wp2010_1007, CEMFI.

Cutler, D. M., Glaeser, E. L., and Vigdor, J. L. (2008). When are ghettos bad? lessons from immigrant segregation in the United States. Journal of Urban Economics, 63(3):759-774.

Damm, A. (2009). Determinants of recent immigrants' location choices: quasi-experimental evidence. Journal of Population Economics, 22(1):145-174.

D'Amuri, F., Ottaviano, G. I., and Peri, G. (2010). The labor market impact of immigration in Western Germany in the 1990. European Economic Review, 54(4):550-570.

Dustmann, C., Fabbri, F., and Preston, I. (2005). The impact of immigration on the British labour market. Economic Journal, 115(507):F324-F341.

Ettner, S. L. (1996). The opportunity costs of elder care. The Journal of Human Resources, 31(1):189-205.

Farrè, L., Gonzalez, L., and Ortega, F. (2011). Immigration, family responsibilities and the labor supply of skilled native women. B.E. Journal of Economic Analysis and Policy: Contributions to Economic Analysis and Policy, 11(1):1-48. 
Gavosto, A., Venturini, A., and Villosio, C. (1999). Do immigrants compete with natives? Labour, 13(3):603621.

Gruber, J. and Wise, D. A. (2004). Social Security Programs and Retirement around the World: MicroEstimation. NBER Books. National Bureau of Economic Research, Inc.

ISTAT (2005). Gli stranieri in Italia: gli effetti dell'ultima regolarizzazione.

Kolodinsky, J. and Shirey, L. (2000). The impact of living with an elder parent on adult daughter's labor supply and hours of work. Journal of Family and Economic Issues, 21:149-175.

Lamura, G., Mnich, E., Nolan, M., Wojszel, B., Krevers, B., Mestheneos, L., and Döhner, H. (2008). Family carers' experiences using support services in Europe: Empirical evidence from the Eurofamcare study. The Gerontologist, 48(6):752-771.

Manacorda, M., Manning, A., and Wadsworth, J. (2012). The impact of immigration on the structure of wages: Theory and evidence from Britain. Journal of the European Economic Association, 10(1):120-151.

Marenzi, A. and Pagani, L. (2008). The labor market participation of sandwich generation Italian women. Journal of Family and Economic Issues, 29(3):427-444.

Ottaviano, G. I. P. and Peri, G. (2012). Rethinking the effect of immigration on wages. Journal of the European Economic Association, 10(1):152-197.

Peri, G. (2007). Immigrants' complementarities and native wages: Evidence from California. NBER Working Papers 12956, National Bureau of Economic Research, Inc.

Peri, G. and Sparber, C. (2011). Highly educated immigrants and native occupational choice. Industrial Relations: A Journal of Economy and Society, 50(3):385-411.

Romiti, A. (2011). Immigrants-natives complementarities in production: evidence from Italy. Cerp working papers, Center for Research on Pensions and Welfare Policies, Turin (Italy).

Samwick, A. A. (1998). New evidence on pensions, social security, and the timing of retirement. Journal of Public Economics, 70(2):207-236.

Staffolani, S. and Valentini, E. (2010). Does immigration raise blue and white collar wages of natives? the case of Italy. Labour, 24(3):295-310.

Stock, J. H. and Wise, D. A. (1990). Pensions, the Option Value of Work, and Retirement. Econometrica, $58(5): 1151-1180$. 
Venturini, A. and Villosio, C. (2006). Labour market effects of immigration into Italy: An empirical analysis. International Labour Review, 145(1-2):91-118.

Wolf, D. A. and Soldo, B. J. (1994). Married women's allocation of time to employment and care of elderly parents. The Journal of Human Resources, 29(4):1259-1276. 
Table 1: Time spent on care of Family Members (weekly hours)

\begin{tabular}{lccccc}
\hline & \multicolumn{2}{c}{ 45 and older } & & \multicolumn{2}{c}{55 and older } \\
\cline { 2 - 3 } \cline { 5 - 6 } & No old par & Old parents & & No old par & Old parents \\
\hline Men & 6.25 & 6.12 & & 6.96 & 7.57 \\
Women & 12.1 & 13.1 & & 11.6 & 16.9 \\
\hline SHIW: 2000 with sampling weights. & & &
\end{tabular}


Table 2: Distribution of Immigrants by Regions and Year

\begin{tabular}{lccc}
\hline & $\mathbf{2 0 0 0}$ & $\mathbf{2 0 0 8}$ & Total \\
\cline { 2 - 4 } Piemonte & 0.023 & 0.080 & 0.045 \\
Valle d'Aosta & 0.017 & 0.059 & 0.039 \\
Lombardia & 0.034 & 0.097 & 0.059 \\
Trentino & 0.025 & 0.077 & 0.047 \\
Veneto & 0.029 & 0.098 & 0.063 \\
Friuli & 0.025 & 0.078 & 0.043 \\
Liguria & 0.020 & 0.062 & 0.036 \\
Emilia & 0.031 & 0.104 & 0.060 \\
Toscana & 0.028 & 0.083 & 0.048 \\
Umbria & 0.031 & 0.098 & 0.056 \\
Marche & 0.026 & 0.086 & 0.042 \\
Lazio & 0.039 & 0.082 & 0.049 \\
Abruzzo & 0.017 & 0.053 & 0.029 \\
Molise & 0.006 & 0.022 & 0.013 \\
Campania & 0.009 & 0.022 & 0.013 \\
Puglia & 0.008 & 0.017 & 0.011 \\
Basilicata & 0.005 & 0.019 & 0.011 \\
Calabria & 0.009 & 0.028 & 0.016 \\
Sicilia & 0.013 & 0.022 & 0.015 \\
Sardegna & 0.006 & 0.016 & 0.011 \\
Total & 0.023 & 0.070 & 0.040 \\
\hline
\end{tabular}

Source: Registry data, 2000-2008. 
Table 3: Instrument Predictive Power. Aggregate Regressions

\begin{tabular}{|c|c|c|c|c|c|c|c|c|}
\hline \multirow[b]{3}{*}{ IV } & \multicolumn{4}{|c|}{ Retirement sample } & \multicolumn{4}{|c|}{ Working/not working sample } \\
\hline & $(1)$ & $(2)$ & (3) & $(4)$ & $(5)$ & (6) & $(7)$ & (8) \\
\hline & $\begin{array}{l}0.9661 * * * \\
(0.1212) \\
\end{array}$ & $\begin{array}{l}0.7829 * * * \\
(0.2170)\end{array}$ & $\begin{array}{l}0.8822 * * * \\
(0.2123)\end{array}$ & $\begin{array}{l}0.7014 * * * \\
(0.2197)\end{array}$ & $\begin{array}{l}0.9661 * * * \\
(0.1212)\end{array}$ & $\begin{array}{l}0.7829 * * * \\
(0.2170)\end{array}$ & $\begin{array}{l}0.8772 * * * \\
(0.2654) \\
\end{array}$ & $\begin{array}{c}0.6606 * \\
(0.2612)\end{array}$ \\
\hline Clust-rob F stats & 63.51 & 13.01 & 17.26 & 10.20 & 63.51 & 13.01 & 10.93 & 6.40 \\
\hline F-stats & 132.30 & 32.89 & 41.41 & 22.98 & 132.30 & 32.89 & 24.96 & 13.96 \\
\hline Obs & 100 & 100 & 100 & 100 & 100 & 100 & 100 & 100 \\
\hline $\begin{array}{l}\text { Controls } \\
\text { Region-year } \\
\text { Full specification } \\
\text { Unemployment rate }\end{array}$ & $\begin{array}{l}\text { No } \\
\text { No } \\
\text { No }\end{array}$ & $\begin{array}{l}\text { Yes } \\
\text { No } \\
\text { No }\end{array}$ & $\begin{array}{l}\text { Yes } \\
\text { Yes } \\
\text { No }\end{array}$ & $\begin{array}{l}\text { Yes } \\
\text { Yes } \\
\text { Yes }\end{array}$ & $\begin{array}{l}\text { No } \\
\text { No } \\
\text { No }\end{array}$ & $\begin{array}{l}\text { Yes } \\
\text { No } \\
\text { No }\end{array}$ & $\begin{array}{l}\text { Yes } \\
\text { Yes } \\
\text { No }\end{array}$ & $\begin{array}{l}\text { Yes } \\
\text { Yes } \\
\text { Yes }\end{array}$ \\
\hline $\begin{array}{l}\text { Note: Each column repre } \\
\text { variable is the immigrant } \\
\text { heading "Retirement sam } \\
\text { working sample" refers t } \\
\text { heading "Full specificatio } \\
\text { eligibility for seniority pe } \\
\text { sample), marital status, } \\
\text { female, dummy for old an } \\
\text { Standard errors in parent }\end{array}$ & $\begin{array}{l}\text { timates fro } \\
\text { f the popula } \\
\text { rs to the re } \\
45 \text { and olde } \\
\text { des the reg } \\
\text { only for the } \\
\text { d its squar } \\
\text { parents. } \\
\text { ustered by }\end{array}$ & $\begin{array}{l}\text { n separate } \mathrm{O} \\
\text { ion at region } \\
\text { ional-time v } \\
\text { ) labor supp } \\
\text { pn-year aver } \\
\text { Retirement } \\
\text { d), time fixe } \\
\text { egion, signifi }\end{array}$ & $\begin{array}{l}\text { regressions } \\
\text { level, and tl } \\
\text { les for the ( } \\
\text { sample. C } \\
\text { of the follo } \\
\text { mple), (log) } \\
\text { effects, regi } \\
\text { nce: }(*) \text { if } p\end{array}$ & $\begin{array}{l}\text { nd older) } \\
\text { mns (1) a } \\
\text { g regresso } \\
\text { worth, er } \\
\text { fixed eff } \\
\left({ }^{* *}\right) \text { if } \mathrm{p}\end{array}$ & $\begin{array}{l}\text { fo analysis } \mathrm{i} \\
\text { cient is its } \mathrm{p} \\
\text { rement sam } \\
\text { (5) include } \\
\text { (predicted) } \\
\text { oyed partne } \\
\text { dummy fo } \\
5,(* * *) \text { if } \mathrm{p}\end{array}$ & $\begin{array}{l}\text { given by reg } \\
\text { dicted value } \\
\text { e, whereas t } \\
\text { nly the prec } \\
\text { V (only for } \\
\text { occupation } \\
\text { old parents } \\
.01 .\end{array}$ & $\begin{array}{l}\text { year. The } \\
\text { mputed as } \\
\text { leading "W } \\
\text { d value, w } \\
\text { Retiremer } \\
\text { ly for the } \\
\text { d its intera }\end{array}$ & $\begin{array}{l}\text { pendent } \\
\text { 2). The } \\
\text { ing/not } \\
\text { reas the } \\
\text { ample), } \\
\text { irement } \\
\text { on with }\end{array}$ \\
\hline
\end{tabular}


Table 4: Summary Statistics: Planned Retirement Sample

\begin{tabular}{lccccc}
\hline \multicolumn{1}{c}{ Variable } & Mean & Std. Dev. & Min. & Max. & N \\
\hline Planned Retir Age & 61.115 & 3.781 & 46 & 70 & 7,876 \\
OV & 0.151 & 0.155 & -0.863 & 0.595 & 7,876 \\
Wealth (log) & 11.526 & 1.889 & 0 & 17.096 & 7,876 \\
Share immigrants & 0.04 & 0.026 & 0.005 & 0.104 & 7,876 \\
Age & 51.439 & 4.724 & 45 & 70 & 7,876 \\
Woman & 0.381 & 0.489 & 0 & 1 & 7,876 \\
Eligible (seniority pens) & 0.039 & 0.195 & 0 & 1 & 7,876 \\
Couple & 0.837 & 0.37 & 0 & 1 & 7,876 \\
Employed Partner & 0.48 & 0.5 & 0 & 1 & 7,876 \\
White col & 0.559 & 0.495 & 0 & 1 & 7,876 \\
Manager & 0.047 & 0.213 & 0 & 1 & 7,876 \\
Blue col & 0.394 & 0.486 & 0 & 1 & 7,876 \\
No edu & 0.013 & 0.098 & 0 & 1 & 7,876 \\
Compuls sch & 0.437 & 0.494 & 0 & 1 & 7,876 \\
Sec sch & 0.413 & 0.493 & 0 & 1 & 7,876 \\
Higher edu & 0.138 & 0.355 & 0 & 1 & 7,876 \\
Old parents & 0.388 & 0.489 & 0 & 1 & 7,876 \\
Low skill old parents & 0.309 & 0.464 & 0 & 1 & 7,876 \\
\hline Source SHIW, 2000-2008 with & sampling weights. & & &
\end{tabular}


Table 5: Planned Retirement Age

\begin{tabular}{|c|c|c|c|c|c|c|c|c|}
\hline & \multicolumn{4}{|c|}{45 and older } & \multicolumn{4}{|c|}{55 and older } \\
\hline & \multicolumn{2}{|c|}{ Men } & \multicolumn{2}{|c|}{ Women } & \multicolumn{2}{|c|}{ Men } & \multicolumn{2}{|c|}{ Women } \\
\hline & $\begin{array}{l}\text { No old } \\
\text { parents }\end{array}$ & $\begin{array}{c}\text { Old } \\
\text { parents }\end{array}$ & $\begin{array}{l}\text { No old } \\
\text { parents }\end{array}$ & $\begin{array}{c}\text { Old } \\
\text { parents }\end{array}$ & $\begin{array}{l}\text { No old } \\
\text { parents }\end{array}$ & $\begin{array}{c}\text { Old } \\
\text { parents }\end{array}$ & $\begin{array}{c}\text { No } \\
\text { parents }\end{array}$ & $\begin{array}{c}\text { Old } \\
\text { parents }\end{array}$ \\
\hline 2000 & 61.2 & 60.3 & 60.1 & 59.3 & 63.4 & 62.4 & 60.8 & 60.9 \\
\hline 2002 & 61.7 & 60.9 & 60.3 & 59.8 & 63.2 & 61.8 & 61.7 & 61.1 \\
\hline 2004 & 62.2 & 61.5 & 60.5 & 60.2 & 63.0 & 62.1 & 61.4 & 61.5 \\
\hline 2006 & 62.0 & 61.6 & 60.9 & 60.4 & 63.1 & 62.0 & 62.3 & 60.3 \\
\hline 2008 & 62.8 & 62.3 & 61.7 & 61.3 & 63.5 & 62.7 & 61.7 & 62.3 \\
\hline
\end{tabular}


Table 6: Summary statistics: Labor Supply Sample

\begin{tabular}{|c|c|c|c|c|c|}
\hline Variable & Mean & Std. Dev. & Min. & Max. & $\mathbf{N}$ \\
\hline Labor supply (Working/not working) & 0.541 & 0.499 & 0 & 1 & 15,763 \\
\hline Labor supply (Weekly hrs) & 37.213 & 8.338 & 3 & 65 & 8,407 \\
\hline Full Time & 0.927 & 0.259 & 0 & 1 & 8,453 \\
\hline Wealth $(\log )$ & 11.521 & 2.01 & 0 & 17.096 & 15,763 \\
\hline Share immigrants & 0.038 & 0.025 & 0.005 & 0.104 & 15,763 \\
\hline Age & 55.666 & 7.119 & 45 & 70 & 15,763 \\
\hline Woman & 0.452 & 0.499 & 0 & 1 & 15,763 \\
\hline Couple & 0.824 & 0.377 & 0 & 1 & 15,763 \\
\hline Employed Partner & 0.354 & 0.479 & 0 & 1 & 15,763 \\
\hline No edu & 0.034 & 0.173 & 0 & 1 & 15,763 \\
\hline Compuls sch & 0.554 & 0.498 & 0 & 1 & 15,763 \\
\hline Sec sch & 0.316 & 0.466 & 0 & 1 & 15,763 \\
\hline Higher edu & 0.096 & 0.303 & 0 & 1 & 15,763 \\
\hline Old parents & 0.345 & 0.477 & 0 & 1 & 15,763 \\
\hline Low skilled old parents & 0.281 & 0.451 & 0 & 1 & 15,763 \\
\hline
\end{tabular}

Source: SHIW, 2000-2008 with sampling weights. 
Table 7: Labor Supply

\begin{tabular}{|c|c|c|c|c|c|c|c|c|}
\hline & \multicolumn{4}{|c|}{45 and older } & \multicolumn{4}{|c|}{55 and older } \\
\hline & \multicolumn{2}{|c|}{ Men } & \multicolumn{2}{|c|}{ Women } & \multicolumn{2}{|c|}{ Men } & \multicolumn{2}{|c|}{ Women } \\
\hline & $\begin{array}{l}\text { No old } \\
\text { parents }\end{array}$ & $\begin{array}{c}\text { Old } \\
\text { parents }\end{array}$ & $\begin{array}{l}\text { No old } \\
\text { parents }\end{array}$ & $\begin{array}{c}\text { Old } \\
\text { parents }\end{array}$ & $\begin{array}{l}\text { No old } \\
\text { parents }\end{array}$ & $\begin{array}{c}\text { Old } \\
\text { parents }\end{array}$ & $\begin{array}{c}\text { No } \\
\text { parents }\end{array}$ & $\begin{array}{c}\text { Old } \\
\text { parents }\end{array}$ \\
\hline & (1) & $(2)$ & (3) & $(4)$ & (5) & (6) & $(7)$ & $(8)$ \\
\hline & \multicolumn{8}{|c|}{ Probability of working } \\
\hline 2000 & 0.54 & 0.63 & 0.37 & 0.46 & 0.24 & 0.36 & 0.13 & 0.20 \\
\hline 2002 & 0.53 & 0.66 & 0.39 & 0.53 & 0.23 & 0.37 & 0.11 & 0.21 \\
\hline 2004 & 0.59 & 0.66 & 0.43 & 0.55 & 0.30 & 0.41 & 0.17 & 0.26 \\
\hline 2006 & 0.57 & 0.67 & 0.48 & 0.58 & 0.28 & 0.43 & 0.22 & 0.34 \\
\hline \multirow[t]{2}{*}{2008} & 0.67 & 0.67 & 0.56 & 0.66 & 0.43 & 0.46 & 0.36 & 0.42 \\
\hline & \multicolumn{8}{|c|}{ Weekly hours (conditional on working) } \\
\hline 2000 & 39.4 & 39.7 & 33.9 & 33.3 & 38.3 & 37.5 & 35.1 & 30.6 \\
\hline 2002 & 39.2 & 39.4 & 33.9 & 34.3 & 38.3 & 39.6 & 32.6 & 33.8 \\
\hline 2004 & 39.1 & 39.2 & 33.9 & 33.8 & 38.8 & 39.6 & 34.3 & 33.4 \\
\hline 2006 & 39.4 & 39.5 & 33.7 & 33.4 & 38.0 & 39.9 & 31.7 & 33.1 \\
\hline \multirow[t]{2}{*}{2008} & 39.9 & 39.3 & 34.4 & 34.4 & 38.9 & 39.6 & 30.9 & 35.0 \\
\hline & \multicolumn{8}{|c|}{ Probability of full time (conditional on working) } \\
\hline 2000 & 0.98 & 0.99 & 0.87 & 0.84 & 0.95 & 0.99 & 0.94 & 0.86 \\
\hline 2002 & 0.98 & 0.98 & 0.85 & 0.85 & 0.95 & 0.96 & 0.84 & 0.78 \\
\hline 2004 & 0.98 & 0.99 & 0.82 & 0.84 & 0.96 & 1.00 & 0.93 & 0.91 \\
\hline 2006 & 0.98 & 0.99 & 0.83 & 0.82 & 0.98 & 0.99 & 0.85 & 0.83 \\
\hline 2008 & 0.97 & 0.99 & 0.85 & 0.86 & 0.97 & 1.00 & 0.82 & 0.94 \\
\hline
\end{tabular}


Table 8: The Effect of Immigration on Planned Retirement Age

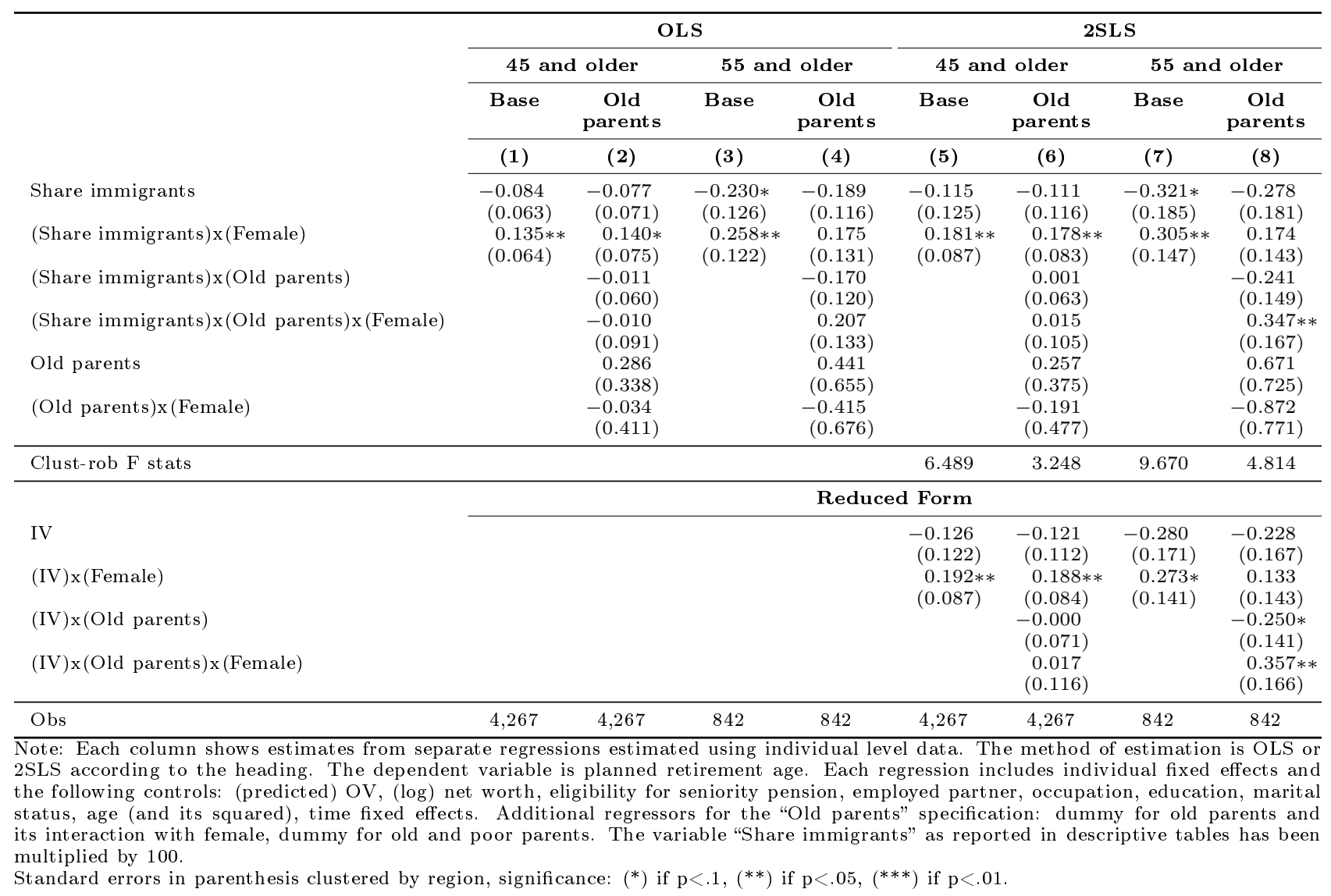


Table 9: The Effect of Immigration on Labor Supply: Working/not Working

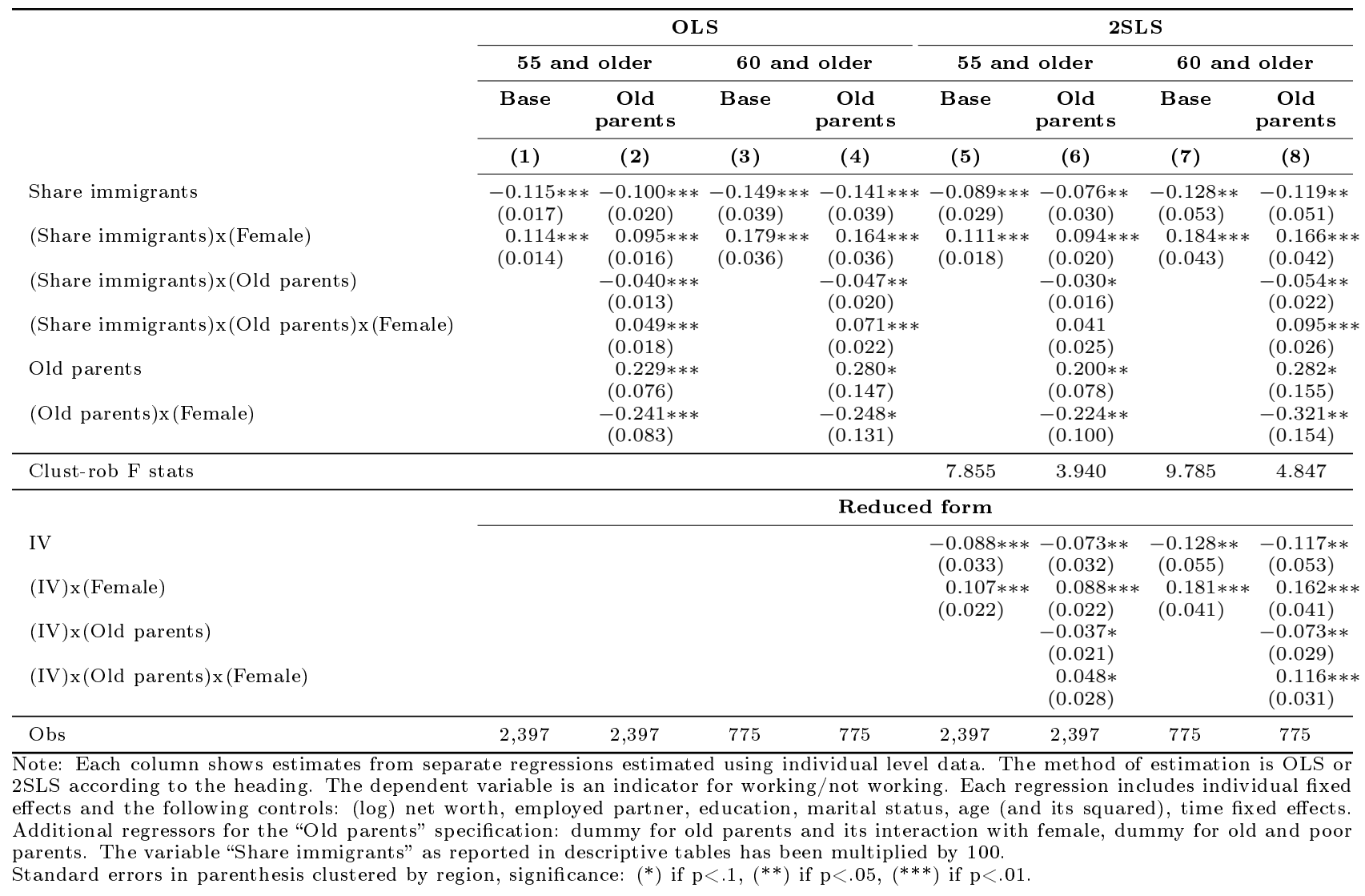


Table 10: The Effect of Immigration on Labor Supply: Weekly Hours Worked and Full time/Part Time

\begin{tabular}{|c|c|c|c|c|c|c|c|c|}
\hline & \multicolumn{4}{|c|}{ OLS } & \multicolumn{4}{|c|}{ 2SLS } \\
\hline & \multicolumn{2}{|c|}{45 and older } & \multicolumn{2}{|c|}{55 and older } & \multicolumn{2}{|c|}{45 and older } & \multicolumn{2}{|c|}{55 and older } \\
\hline & Base & $\begin{array}{c}\text { Old } \\
\text { parents }\end{array}$ & Base & $\begin{array}{c}\text { Old } \\
\text { parents }\end{array}$ & Base & $\begin{array}{c}\text { Old } \\
\text { parents }\end{array}$ & Base & $\begin{array}{c}\text { Old } \\
\text { parents }\end{array}$ \\
\hline & (1) & $(2)$ & (3) & (4) & (5) & (6) & $(7)$ & $(8)$ \\
\hline & \multicolumn{8}{|c|}{ Weekly working hours } \\
\hline Share immigrants & $\begin{array}{l}-0.015 * * * \\
(0.004)\end{array}$ & $\begin{array}{l}-0.016 * * * \\
(0.006)\end{array}$ & $\begin{array}{l}-0.006 \\
(0.017)\end{array}$ & $\begin{array}{c}0.001 \\
(0.015)\end{array}$ & $\begin{array}{c}-0.011 * \\
(0.006)\end{array}$ & $\begin{array}{c}-0.009 \\
(0.006)\end{array}$ & $\begin{array}{r}-0.006 \\
(0.019)\end{array}$ & $\begin{array}{c}0.003 \\
(0.018)\end{array}$ \\
\hline (Share immigrants)x(Female) & $\begin{array}{c}0.001 \\
(0.005)\end{array}$ & $\begin{array}{r}-0.002 \\
(0.006)\end{array}$ & $\begin{array}{c}0.006 \\
(0.020)\end{array}$ & $\begin{array}{r}-0.004 \\
(0.020)\end{array}$ & $\begin{array}{c}0.000 \\
(0.006)\end{array}$ & $\begin{array}{l}-0.003 \\
(0.006)\end{array}$ & $\begin{array}{c}0.007 \\
(0.023)\end{array}$ & $\begin{array}{c}0.002 \\
(0.019)\end{array}$ \\
\hline (Share immigrants)x(Old parents) & & $\begin{array}{c}0.001 \\
(0.005)\end{array}$ & & & & & & \\
\hline (Share immigrants $) x($ Old parents $) x($ Female $)$ & & 0.007 & & 0.033 & & 0.008 & & 0.018 \\
\hline & & $(0.007)$ & & $(0.024)$ & & $(0.007)$ & & $(0.028)$ \\
\hline Old parents & & 0.027 & & $0.184 * *$ & & $0.040 * *$ & & $0.194 * * *$ \\
\hline & & $(0.020)$ & & $(0.075)$ & & $(0.019)$ & & $(0.064)$ \\
\hline (Old parents) $\mathrm{x}$ (Female) & & -0.044 & & $-0.291 *$ & & -0.048 & & -0.232 \\
\hline & & $(0.041)$ & & $(0.153)$ & & $(0.043)$ & & $(0.162)$ \\
\hline Clust-rob F stats & & & & & 7.014 & 3.530 & 10.189 & 5.010 \\
\hline \multirow[t]{2}{*}{ Obs } & 4,650 & 4,650 & 949 & 949 & 4,650 & 4,650 & 949 & 949 \\
\hline & \multicolumn{8}{|c|}{ Full time/Part time } \\
\hline Share immigrants & $\begin{array}{r}-0.003 \\
(0.003)\end{array}$ & $\begin{array}{r}-0.001 \\
(0.003)\end{array}$ & $\begin{array}{c}0.001 \\
(0.010)\end{array}$ & $\begin{array}{c}0.004 \\
(0.009)\end{array}$ & $\begin{array}{c}0.004 \\
(0.004)\end{array}$ & $\begin{array}{l}0.006 \\
(0.005)\end{array}$ & $\begin{array}{c}0.022 \\
(0.017)\end{array}$ & $\begin{array}{c}0.024 \\
(0.017)\end{array}$ \\
\hline (Share immigrants)x(Female) & 0.002 & -0.004 & -0.013 & -0.021 & 0.001 & -0.004 & -0.014 & -0.022 \\
\hline (Share immiorants)y (Old peronts) & $(0.002)$ & $(0.003)$ & $(0.016)$ & $(0.017)$ & $(0.003)$ & $(0.004)$ & $(0.017)$ & $(0.017)$ \\
\hline & & $(0.002)$ & & $(0.007)$ & & $\begin{array}{c}-0.005 * \\
(0.003)\end{array}$ & & $\begin{array}{r}-0.009 \\
(0.007)\end{array}$ \\
\hline (Share immigrants)x(Old parents $) x($ Female $)$ & & $0.012 * * *$ & & $0.024 *$ & & $0.012 * *$ & & 0.024 \\
\hline Old parents & & $(0.005)$ & & $(0.014)$ & & $(0.006)$ & & $(0.020)$ \\
\hline & & $(0.012)$ & & $(0.055)$ & & $(0.013)$ & & $(0.055)$ \\
\hline (Old parents)x(Female) & & -0.047 & & -0.071 & & -0.045 & & -0.082 \\
\hline & & $(0.029)$ & & $(0.044)$ & & $(0.031)$ & & $(0.058)$ \\
\hline Clust-rob F stats & & & & & 6.921 & 3.479 & 10.151 & 4.990 \\
\hline Obs & 4,679 & 4,679 & 952 & 952 & 4,679 & 4,679 & 952 & 952 \\
\hline \multicolumn{9}{|c|}{$\begin{array}{l}\text { Note: Each column shows estimates from separate regressions estimated using individual level data. The method of estimation is OLS } \\
\text { or 2SLS according to the heading. The dependent variables are: (log) weekly hours of work conditional on working (Top panel) and an } \\
\text { indicator for working full-time vs part-time conditional on working (Bottom panel). Each regression includes individual fixed effects and } \\
\text { the following controls: (log) net worth, employed partner, education, marital status, age (and its squared), time fixed effects. Additional } \\
\text { regressors for the "Old parents" specification: dummy for old parents and its interaction with female, dummy for old and poor parents. The } \\
\text { variable "Share immigrants" as reported in descriptive tables has been multiplied by } 100 \text {. } \\
\text { Standard errors in parenthesis clustered by region, significance: }(*) \text { if } p<.1,(* *) \text { if } p<.05,(* * *) \text { if p<.01. }\end{array}$} \\
\hline
\end{tabular}


Table 11: 2SLS-FE. The Effect of Immigration on Planned Retirement Age and Working/not Working by Education Level

\begin{tabular}{|c|c|c|c|c|c|c|c|c|}
\hline & \multicolumn{4}{|c|}{45 and older } & \multicolumn{4}{|c|}{55 and older } \\
\hline & \multicolumn{2}{|c|}{ High education } & \multicolumn{2}{|c|}{ Low education } & \multicolumn{2}{|c|}{ High education } & \multicolumn{2}{|c|}{ Low education } \\
\hline & Base & $\begin{array}{c}\text { Old } \\
\text { parents }\end{array}$ & Base & $\begin{array}{c}\text { Old } \\
\text { parents }\end{array}$ & Base & $\begin{array}{c}\text { Old } \\
\text { parents }\end{array}$ & Base & $\begin{array}{c}\text { Old } \\
\text { parents }\end{array}$ \\
\hline & (1) & $(2)$ & (3) & (4) & (5) & (6) & (7) & (8) \\
\hline & \multicolumn{8}{|c|}{ Planned retirement age } \\
\hline Share immigrants & $\begin{array}{c}0.044 \\
(0.132)\end{array}$ & $\begin{array}{c}0.026 \\
(0.144)\end{array}$ & $\begin{array}{c}-0.242 \\
(0.182)\end{array}$ & $\begin{array}{c}-0.231 \\
(0.152)\end{array}$ & $\begin{array}{c}-0.072 \\
(0.263)\end{array}$ & $\begin{array}{r}-0.032 \\
(0.273)\end{array}$ & $\begin{array}{l}-0.727 * * * \\
(0.215)\end{array}$ & $\begin{array}{l}-0.677 * * * \\
(0.197)\end{array}$ \\
\hline (Share immigrants) $x$ (Female) & $\begin{array}{l}0.144 * * \\
(0.061)\end{array}$ & $\begin{array}{c}0.173 * \\
(0.091)\end{array}$ & $\begin{array}{c}0.220 \\
(0.146)\end{array}$ & $\begin{array}{r}0.237 * \\
(0.122)\end{array}$ & $\begin{array}{l}0.105 \\
(0.163)\end{array}$ & $\begin{array}{c}0.082 \\
(0.160)\end{array}$ & $\begin{array}{l}0.737 * * * \\
(0.199)\end{array}$ & $\begin{array}{l}0.510 * * \\
(0.205)\end{array}$ \\
\hline (Share immigrants)x(Old parents) & & $\begin{array}{c}0.032 \\
(0.070)\end{array}$ & & $\begin{array}{c}-0.007 \\
(0.108)\end{array}$ & & $\begin{array}{c}-0.1006 \\
-0.143)\end{array}$ & & $\begin{array}{c}-0.324 \\
(0.291)\end{array}$ \\
\hline$($ Share immigrants $) \mathrm{x}($ Old parents $) \mathrm{x}($ Female $)$ & & $\begin{array}{c}-0.056 \\
(0.117)\end{array}$ & & $\begin{array}{r}-0.018 \\
(0.115)\end{array}$ & & $\begin{array}{c}-0.102 \\
(0.271)\end{array}$ & & $\begin{array}{l}0.617 * * \\
(0.296)\end{array}$ \\
\hline Old parents & & $\begin{array}{c}0.026 \\
(0.323)\end{array}$ & & $\begin{array}{c}0.487 \\
(0.674)\end{array}$ & & $\begin{array}{c}0.773 \\
(0.817)\end{array}$ & & $\begin{array}{l}1.038 \\
(1.217)\end{array}$ \\
\hline (Old parents $) x($ Female $)$ & & $\begin{array}{c}0.142 \\
(0.569)\end{array}$ & & $\begin{array}{c}-0.171 \\
(0.637)\end{array}$ & & $\begin{array}{c}0.862 \\
(1.097)\end{array}$ & & $\begin{array}{c}-2.562 * \\
(1.476)\end{array}$ \\
\hline \multirow[t]{2}{*}{ Obs } & 2,207 & 2,207 & 2,204 & 2,204 & 462 & 462 & 375 & 375 \\
\hline & \multicolumn{8}{|c|}{ Labor supply: Working/not working } \\
\hline Share immigrants & $\begin{array}{c}-0.026 \\
(0.018)\end{array}$ & $\begin{array}{r}-0.023 \\
(0.019)\end{array}$ & $\begin{array}{l}-0.046 * * * \\
(0.014)\end{array}$ & $\begin{array}{c}*-0.046 * * * \\
(0.015)\end{array}$ & $\begin{array}{c}-0.028 \\
(0.048)\end{array}$ & $\begin{array}{c}-0.020 \\
(0.046)\end{array}$ & $\begin{array}{l}-0.153 * * * \\
(0.040)\end{array}$ & $\begin{array}{l}-0.130 * * * \\
(0.044)\end{array}$ \\
\hline (Share immigrants) $x($ Female $)$ & $\begin{array}{c}0.010 \\
(0.010)\end{array}$ & $\begin{array}{c}0.016 * \\
(0.010)\end{array}$ & $\begin{array}{l}0.061 * * * \\
(0.011)\end{array}$ & $\begin{array}{l}0.059 * * * \\
(0.013)\end{array}$ & $\begin{array}{r}0.041 * \\
(0.021)\end{array}$ & $\begin{array}{l}0.041 * * \\
(0.019)\end{array}$ & $\begin{array}{l}0.160 * * * \\
(0.030)\end{array}$ & $\begin{array}{l}0.135 * * * \\
(0.034)\end{array}$ \\
\hline (Share immigrants)x(Old parents) & & $\begin{array}{r}-0.006 \\
(0.009)\end{array}$ & & $\begin{array}{c}-0.004 \\
(0.007)\end{array}$ & & $\begin{array}{c}-0.038 \\
(0.026)\end{array}$ & & $\begin{array}{c}-0.029 \\
(0.021)\end{array}$ \\
\hline$($ Share immigrants $) x($ Old parents $) x($ Female $)$ & & -0.009 & & 0.014 & & $\begin{array}{r}-0.016 \\
(0.042)\end{array}$ & & $\begin{array}{l}0.059 * * \\
(0.024)\end{array}$ \\
\hline Old parents & & 0.007 & & $0.117 * * *$ & & 0.096 & & $0.299 * * *$ \\
\hline (Old parents)x(Female) & & $\begin{array}{c}(0.033) \\
0.003 \\
(0.048)\end{array}$ & & $\begin{array}{c}(0.044) \\
-0.141 * * \\
(0.056)\end{array}$ & & $\begin{array}{c}(0.130) \\
-0.060 \\
(0.153)\end{array}$ & & $\begin{array}{c}(0.097) \\
-0.354 * * * \\
(0.095)\end{array}$ \\
\hline Obs & 2,880 & 2,880 & 4,213 & 4,213 & 804 & 804 & 1,566 & 1,566 \\
\hline $\begin{array}{l}\text { te: Each column shows estimates from se } \\
\text { ng individual level data. The method of es } \\
\text { icator for working/not working (Bottom p } \\
\text { rth, employed partner, education, marital } \\
\text { cification: dummy for old parents and its } \\
\text { y for the planned retirement age specifica }\end{array}$ & te regi & $\begin{array}{l}\text { is on } \\
\text { S. Th }\end{array}$ & ifferen & $\begin{array}{l}\text { samples brok } \\
\text { ariables are: } \\
\text { ividual fixed } \\
\text { fixed effects. } \\
\text { or old and pc } \\
\text { seniority per }\end{array}$ & $\begin{array}{l}\text { ken dov } \\
\text { planne } \\
\text { effects } \\
\text { Additi } \\
\text { oor par } \\
\text { nsion, }\end{array}$ & $\begin{array}{l}\text { y educa } \\
\text { irement } \\
\text { the foll } \\
\text { regress } \\
\text { Addit } \\
\text { occupat }\end{array}$ & $\begin{array}{l}\text { level and } \\
\text { (Top pan } \\
\text { ig controls } \\
\text { for the "Ol } \\
\text { l regressor } \\
\text { The varia }\end{array}$ & $\begin{array}{l}\text { estimated } \\
\text { el) and an } \\
\text { : (log) net } \\
\text { ld parents" } \\
\text { rs included } \\
\text { able "Share }\end{array}$ \\
\hline
\end{tabular}


Table 12: 2SLS-FE. The Effect of Immigration on Planned Retirement Age and Working/not Working by Wealth

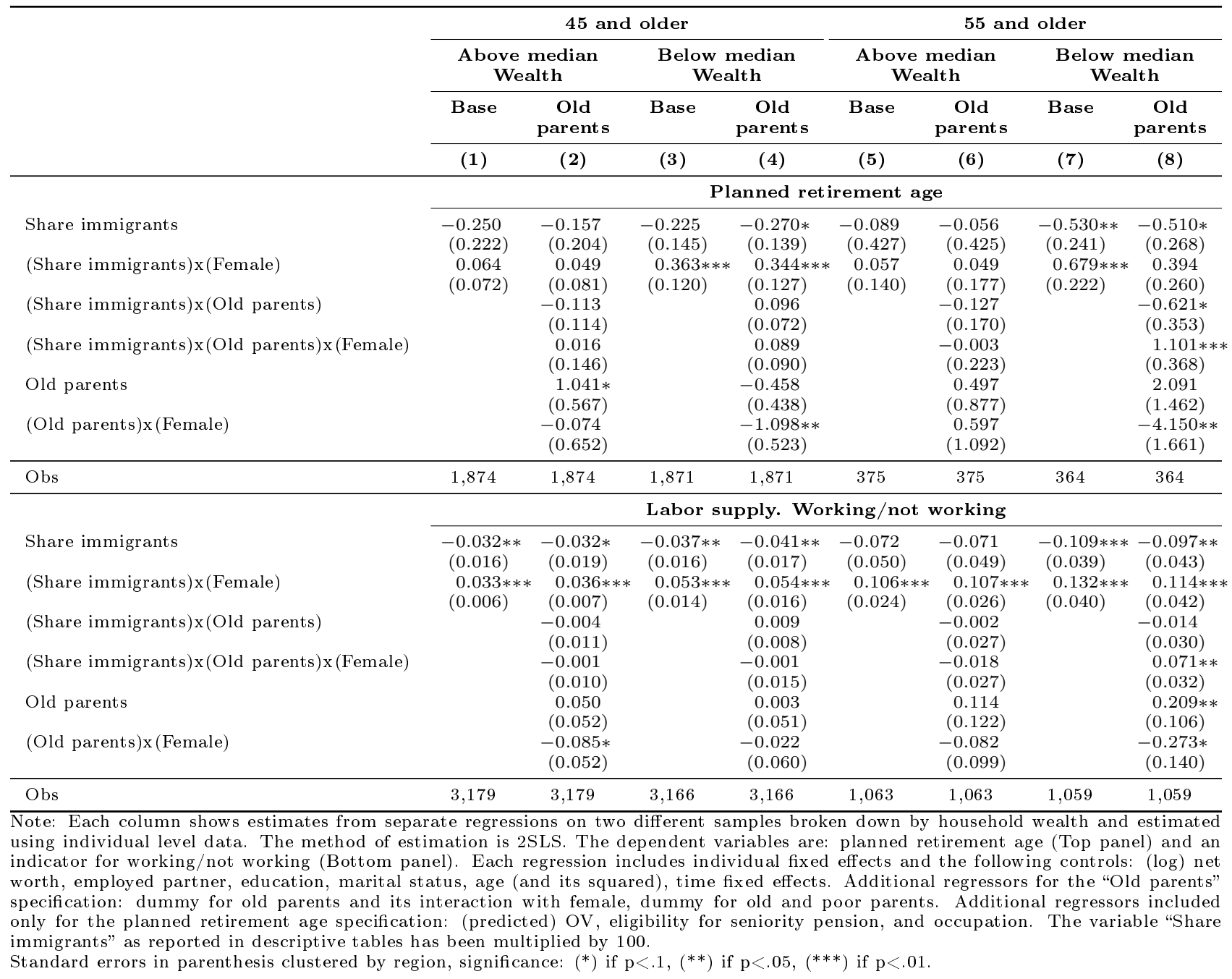


Table 13: 2SLS-FE. Robustness. Control for Local Demand Factors, Daughters' Contribution to Household Services, and Correction for Illegals

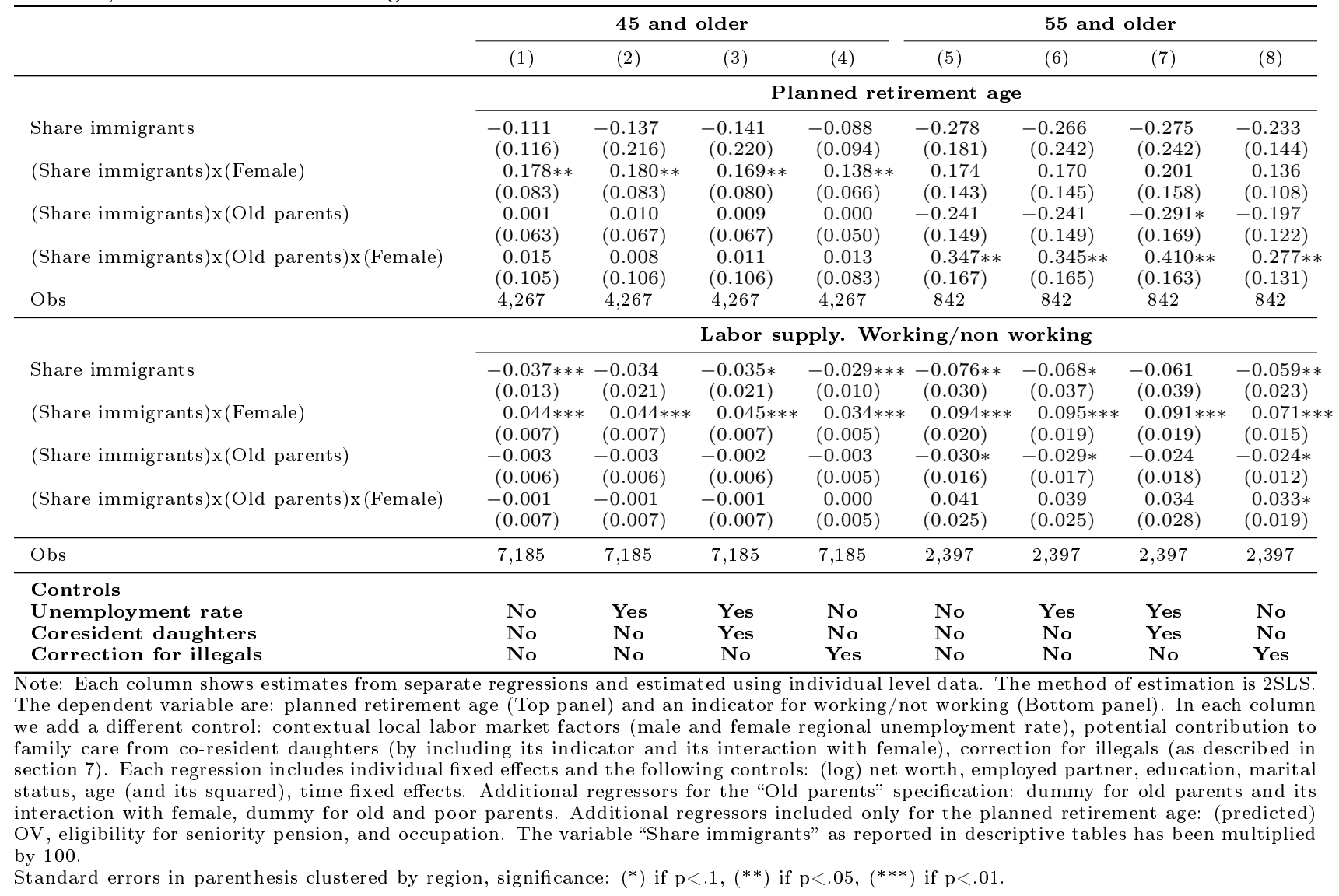


Table 14: Predicted Impact of Immigration

\begin{tabular}{|c|c|c|c|c|c|c|c|c|c|}
\hline & $(1)$ & $(2)$ & $(3)$ & $(4)$ & $(5)$ & $(6)$ & $(7)$ & $(8)$ & $(9)$ \\
\hline & \multicolumn{4}{|c|}{ Planned retirement age (months) } & \multicolumn{5}{|c|}{ Working/not working } \\
\hline & \multicolumn{2}{|c|}{45 and older } & \multicolumn{2}{|c|}{55 and older } & \multicolumn{2}{|c|}{45 and older } & \multicolumn{2}{|c|}{55 and older } & 60 and older \\
\hline \multirow{2}{*}{$\begin{array}{l}\text { Women } \\
\text { Women with } \\
\text { old parents }\end{array}$} & \multicolumn{2}{|c|}{+2.2} & \multicolumn{2}{|c|}{$\begin{array}{l}+3.6 \\
+4.2\end{array}$} & \multicolumn{2}{|c|}{$+4 \mathrm{pp}$} & \multicolumn{2}{|c|}{$+9 \mathrm{pp}$} & $+16 \mathrm{pp}$ \\
\hline & $\begin{array}{c}\text { Below } \\
\text { median } \\
\text { wealth }\end{array}$ & $\begin{array}{c}\text { Above } \\
\text { median } \\
\text { wealth }\end{array}$ & $\begin{array}{c}\text { Below } \\
\text { median } \\
\text { wealth }\end{array}$ & $\begin{array}{c}\text { Above } \\
\text { median } \\
\text { wealth }\end{array}$ & $\begin{array}{c}\text { Below } \\
\text { median } \\
\text { wealth }\end{array}$ & $\begin{array}{c}\text { Above } \\
\text { median } \\
\text { wealth }\end{array}$ & $\begin{array}{c}\text { Below } \\
\text { median } \\
\text { wealth }\end{array}$ & $\begin{array}{c}\text { Above } \\
\text { median } \\
\text { wealth }\end{array}$ & \\
\hline \multirow{2}{*}{$\begin{array}{l}\text { Women } \\
\text { Women with } \\
\text { old parents }\end{array}$} & +4.3 & & $\begin{array}{l}+8.1 \\
+13.2\end{array}$ & & $+5 \mathrm{pp}$ & $+3 \mathrm{pp}$ & $\begin{array}{l}+13 p p \\
+7 p p\end{array}$ & $+11 p p$ & \\
\hline & $\begin{array}{c}\text { Low } \\
\text { education }\end{array}$ & $\begin{array}{c}\text { High } \\
\text { education }\end{array}$ & $\begin{array}{c}\text { Low } \\
\text { education }\end{array}$ & $\begin{array}{c}\text { High } \\
\text { education }\end{array}$ & $\begin{array}{c}\text { Low } \\
\text { education }\end{array}$ & $\begin{array}{c}\text { High } \\
\text { education }\end{array}$ & $\begin{array}{c}\text { Low } \\
\text { education }\end{array}$ & $\begin{array}{c}\text { High } \\
\text { education }\end{array}$ & \\
\hline \multirow{3}{*}{$\begin{array}{l}\text { Women } \\
\text { Women with } \\
\text { old parents }\end{array}$} & & +1.73 & $\begin{array}{l}+8.84 \\
+7.40\end{array}$ & & $+6 \mathrm{pp}$ & & $\begin{array}{l}+16 \mathrm{pp} \\
+6 \mathrm{pp}\end{array}$ & $+4 \mathrm{pp}$ & \\
\hline & \multicolumn{4}{|c|}{ Full time/part time } & \multicolumn{4}{|c|}{ Weekly working hours } & \\
\hline & \multicolumn{2}{|c|}{45 and older } & \multicolumn{2}{|c|}{55 and older } & \multicolumn{2}{|c|}{45 and older } & \multicolumn{2}{|c|}{55 and older } & \\
\hline \multirow{2}{*}{$\begin{array}{l}\text { Women } \\
\text { Women with } \\
\text { old parents }\end{array}$} & $+1 \mathrm{pp}$ & & & & & & & & \\
\hline & $\begin{array}{c}\text { Below } \\
\text { median } \\
\text { wealth }\end{array}$ & $\begin{array}{c}\text { Above } \\
\text { median } \\
\text { wealth }\end{array}$ & $\begin{array}{c}\text { Below } \\
\text { median } \\
\text { wealth }\end{array}$ & $\begin{array}{c}\text { Above } \\
\text { median } \\
\text { wealth }\end{array}$ & $\begin{array}{c}\text { Below } \\
\text { median } \\
\text { wealth }\end{array}$ & $\begin{array}{c}\text { Above } \\
\text { median } \\
\text { wealth }\end{array}$ & $\begin{array}{c}\text { Below } \\
\text { median } \\
\text { wealth }\end{array}$ & $\begin{array}{c}\text { Above } \\
\text { median } \\
\text { wealth }\end{array}$ & \\
\hline \multirow[t]{2}{*}{$\begin{array}{l}\text { Women } \\
\text { Women with } \\
\text { old parents }\end{array}$} & & & & & & & & & \\
\hline & $\begin{array}{c}\text { Low } \\
\text { education }\end{array}$ & $\begin{array}{c}\text { High } \\
\text { education }\end{array}$ & $\begin{array}{c}\text { Low } \\
\text { education }\end{array}$ & $\begin{array}{c}\text { High } \\
\text { education }\end{array}$ & $\begin{array}{c}\text { Low } \\
\text { education }\end{array}$ & $\begin{array}{c}\text { High } \\
\text { education }\end{array}$ & $\begin{array}{c}\text { Low } \\
\text { education }\end{array}$ & $\begin{array}{c}\text { High } \\
\text { education }\end{array}$ & \\
\hline $\begin{array}{l}\text { Women } \\
\text { Women with } \\
\text { old parents }\end{array}$ & $+2 \mathrm{pp}$ & & & & & & $+3 \mathrm{hrs}$ & & \\
\hline
\end{tabular}


Figure 1: Immigrant inflow as share of the Population by Country of origin

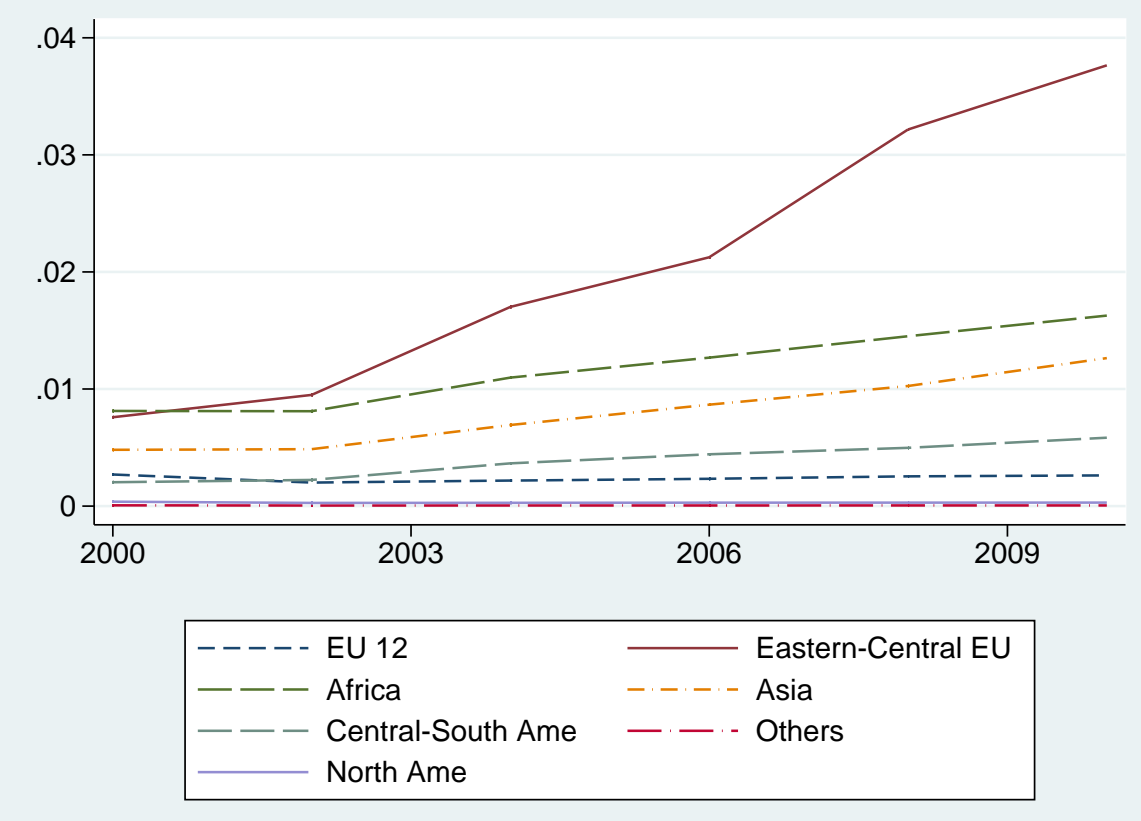

Source: authors' calculation from registry data (2000-2010) 


\section{Appendix}

\section{A1. Theoretical appendix}

We describe briefly here a model in the spirit of Chan and Stevens (2004) that can be used to justify the role of lowering the cost of caring for older parents on the retirement decision. It follows the Option Value approach pioneered by Stock and Wise (1990). This model expands upon Chan and Stevens (2004) in two main respects: we introduce the non separability between leisure and consumption and we enrich their model allowing for the role of the long-term care costs related to parental care. As Stock and Wise (1990) and Chan and Stevens (2004) our model is a modified version of the standard life-cycle approach with a leisure enhancing factor entering the utility function only after retirement. Individuals are assumed to maximize the following inter-temporal and separable utility function, with a Constant Relative Risk Aversion (CRRA) form:

$$
\max _{c_{t}} U\left(c_{t}, c_{t+1}, \ldots, c_{T}\right)=\max _{c_{t}, c_{t+1} . . c_{T}} \sum_{s=t}^{R} \frac{\left(c_{s}\right)^{1-\gamma}}{(1+\rho)^{s-t}(1-\gamma)}+\sum_{s=R+1}^{T} \frac{\left(k c_{s}\right)^{1-\gamma}}{(1+\rho)^{s-t}(1-\gamma)}
$$

where $c$ is consumption level, $1 / \gamma$ is the inter-temporal elasticity of substitution, $\rho$ is the subjective discount rate, $T$ the expected lifetime, and $k>1$ is a factor enhancing utility when individuals enjoy free time. It captures, in other words, the leisure in the utility function which we suppose the individual can enjoy if she/he does neither work nor takes care of her/his parents. $R$ is the age at which individuals retire and $T$ is the end of lifetime (known with certainty).

The inter-temporal budget constraint can be written as follows:

$$
\begin{gathered}
\sum_{s=t}^{T} \frac{c_{s}}{(1+r)^{s-t}}=A_{t}+\sum_{s=t}^{R} \frac{y_{s}}{(1+r)^{s-t}}+\sum_{s=R+1}^{T} \frac{B_{s}}{(1+r)^{s-t}} \\
\sum_{s=t}^{T} \frac{c_{s}}{(1+r)^{s-t}}=A_{t}+\sum_{s=t}^{R_{2}} \frac{y_{s}}{(1+r)^{s-t}}+\sum_{s=R_{2}+1}^{T} \frac{\bar{B}_{s}}{(1+r)^{s-t}}-\sum_{s=R+1}^{R_{2}} \frac{y_{s}^{c}}{(1+r)^{s-t}}
\end{gathered}
$$

where $y$ and $B$ are labor income and pension benefits, respectively, $A_{t}$ is the sum of real and financial wealth, and $r$ is the annual interest rate, supposed to be known and constant over time. ${ }^{21}$ After solving the maximization problem, ${ }^{22}$ the relevant value function is the sum of flows of future utility when consumption is chosen at its optimal level:

$$
V_{t}\left(R, A_{t}\right)=\left(\sum_{s=t}^{R} y_{s}+\sum_{s=R+1}^{T} B_{s}+A_{t}\right)^{1-\gamma} \frac{\left(R-t+1+k^{\frac{1-\gamma}{\gamma}}(T-R)\right)^{\gamma}}{(1-\gamma)}
$$

\footnotetext{
${ }^{21}$ Uncertainty is removed from the model by assuming that individuals know with certainty their expected end of life.

${ }^{22}$ We assume here for simplicity $r=\rho$ and equal to zero, though the general case with $r \neq 0$ provides the same testable implication and it is available upon request.
} 
For individuals deciding to postpone retirement optimally to $\bar{R}>R$ it must hold that:

$$
V_{t}\left(\bar{R}, A_{t}\right)>V_{t}\left(R, A_{t}\right)
$$

where

$$
V_{t}\left(\bar{R}, A_{t}\right)=\left(\sum_{s=t}^{\bar{R}} y_{s}+\sum_{s=\bar{R}+1}^{T} \bar{B}_{s}+A_{t}\right)^{1-\gamma} \frac{\left(\bar{R}-t+1+k^{\frac{1-\gamma}{\gamma}}(T-\bar{R})\right)^{\gamma}}{(1-\gamma)}
$$

with $\bar{B}>B$. Takings logs of (6) follows that for individuals deciding to postpone retirement the following inequality must hold.

$$
\log \left(H_{\bar{R}}\right)-\log \left(H_{R}\right)>\frac{\gamma}{1-\gamma} \log \left[\frac{R-t+1+k^{\frac{1-\gamma}{\gamma}}(T-R)}{\bar{R}-t+1+k^{\frac{1-\gamma}{\gamma}}(T-\bar{R})}\right]
$$

where $H_{\bar{R}}$ and $H_{R}$ are the amount of resources under postponed retirement and early retirement, respectively.

$$
H_{\bar{R}}=\sum_{s=t}^{\bar{R}} y_{s}+\sum_{s=\bar{R}+1}^{T} \bar{B}_{s}+A_{t}
$$

and

$$
H_{R}=\sum_{s=t}^{R} y_{s}+\sum_{s=R+1}^{T} B_{s}+A_{t}
$$

We now introduce the possibility of taking care of the old parents when the individual is entitled to retirement, which is after age $R$. Suppose that the parents are alive until age $R_{3}$, which is higher than the early possible retirement age $(R)$ and the maximum retirement age allowed $\left(R_{2}\right)$. If the care of parents is bought in the market and the agent continues working up to $R_{2}$, we have the following inter-temporal utility function:

$$
\max _{c_{t}} U\left(c_{t}, c_{t+1}, \ldots, c_{T}\right)=\max _{c_{s}} \sum_{s=t}^{R_{3}} \frac{\left(c_{s}\right)^{1-\gamma}}{(1+\rho)^{s-t}(1-\gamma)}+\sum_{s=R_{3}+1}^{T} \frac{\left(k c_{s}\right)^{1-\gamma}}{(1+\rho)^{s-t}(1-\gamma)}
$$

subject to the following inter-temporal budget constraint

$$
\sum_{s=t}^{T} \frac{c_{s}}{(1+r)^{s-t}}=A_{t}+\sum_{s=t}^{R_{2}} \frac{y_{s}}{(1+r)^{s-t}}+\sum_{s=R_{2}+1}^{T} \frac{\bar{B}_{s}}{(1+r)^{s-t}}-\sum_{s=R+1}^{R_{2}} \frac{y_{s}^{c}}{(1+r)^{s-t}}
$$

Individuals start enjoying leisure only after $R_{3}$, which corresponds to their parents' death and we assume that they optimally decide to postpone the possible early retirement age $R$ to $R_{2}<R_{3}$ by paying the market cost of long-term care $y^{c}=w^{c} h$, for the time interval $R_{2}-R$, where $w^{c}$ is the hourly salary for elderly care-givers with $y_{s}>y_{s}^{c}$. After some algebra it follows that a similar inequality to (8) must hold: 


$$
\log \left(H_{\bar{R}}\right)-\log \left(H_{R}\right)>\frac{\gamma}{1-\gamma} \log \left[\frac{(R-t+1)+k^{\frac{1-\gamma}{\gamma}}(T-R)}{\left(R_{3}-t+1\right)+k^{\frac{1-\gamma}{\gamma}}\left(T-R_{3}\right)}\right]
$$

where

$$
H_{\bar{R}}=\sum_{s=t}^{R_{2}} y_{s}+\sum_{s=R_{2}+1}^{T} \bar{B}_{s}+A_{t}-\sum_{s=R+1}^{R_{2}} y_{s}^{c}
$$

and

$$
H_{R}=\sum_{s=t}^{R} y_{s}+\sum_{s=R+1}^{T} B_{s}+A_{t}
$$

The testable implication is derived by taking the first derivative of equation (11) with respect to the market cost of long-term care, $y^{c}$. The main intuition is that a reduction in the market cost of long term care has a positive impact on the retirement age, as follows:

$$
\frac{\partial \log \left(H_{\bar{R}}\right)-\log \left(H_{R}\right)}{\partial y^{c}}=-\frac{1}{\left(\sum_{s=t}^{R_{2}} y_{s}+\sum_{s=R_{2}+1}^{T} \bar{B}_{s}+A_{t}-\sum_{s=R+1}^{R_{2}} y_{s}^{c}\right)}<0
$$

\section{A2. OV, earnings, and pension benefits projection}

Our measure of the OV is computed as the left hand side of equation (11), where $H_{\bar{R}}$, and $\left(H_{R}\right)$ are the sum of life-time resources including the sums of net worth wealth, labor earnings, and pension benefits. ${ }^{23}$ In order to compute the sum of life-time resources we need to recover individual life-expectancy. First we assume that individuals know with certainty the expected end of their life, $(T)$ which we take for each respondent from the life-tables, disaggregated by year, gender, age and geographic location (defined by five macro-regions and provided by ISTAT). Second, for each worker we need to compute the expected pension benefits, $\bar{B}$, thus we need to project forward their earnings to the year before their expected retirement and to apply the expected replacement rate. Therefore, individual earnings are projected forward up to the year prior to the expected retirement, applying the constant growth rate of real earnings per capita corresponding to the last year in which they featured in the sample. We compute the per capita (real) earning growth rate by using the growth rate of earning at national level. ${ }^{24}$ In addition, in order to compute the pension benefit in cases of immediate retirement, $B$, we need to recover the expected replacement rate corresponding to the last year in which the

\footnotetext{
${ }^{23}$ Since we do not have information on wages, we cannot include the market cost of elderly care in $H_{\bar{R}}$. The immigration variable included in equation (1) controls for the impact of immigrants both on availability and on market cost of household services.

${ }^{24}$ For an alternative earnings projection strategy see Borella and Moscarola (2010) who model individual earnings profiles by using a regression model, which controls for age, cohort, regional and time dummies, plus and additional individual random effect, and with the error term following an $\mathrm{AR}(1)$ process.
} 
individuals featured in the sample. However, the data provides only the expected replacement rate for the year when the respondent expects to retire. We therefore predict the expected replacement rate using the following regression:

$$
y_{i t}=\beta z_{i t}+x_{i t}^{\prime} \gamma+D_{t}+\epsilon_{i t}
$$

where $y_{i t}$ is the expected replacement rate provided by the survey and $z_{i t}$ represents the years of contributions expected to be paid before retirement. In order to compute the latter variable, we use the information provided by the survey regarding the number of years of contributions paid by workers at the time of the interview, and we assume that each worker would pay contributions for the remaining years up to their expected retirement age. $x_{i t}$ is a vector of individual characteristics including gender, education, type of occupation and civil status, $D_{t}$ is a time dummy and $\epsilon_{i t}$ is the standard zero-mean error term. We then use the coefficients estimated in equation (12) to predict the expected replacement rate corresponding to immediate retirement. This predicted value is applied to the earnings corresponding to the penultimate year to recover the immediate benefits $(B)$. In the computation of $H_{\bar{R}}$ and $H_{R}$, both $\bar{B}$ and $B$ are assumed to be constant. All financial values are expressed in real terms, deflated using the CPI-based index with base $=2005$. 